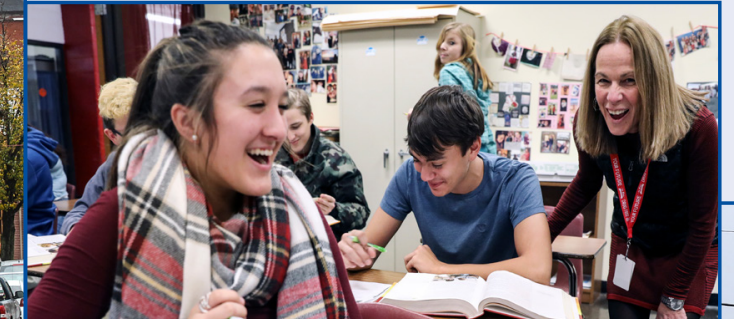

Community Mat ters

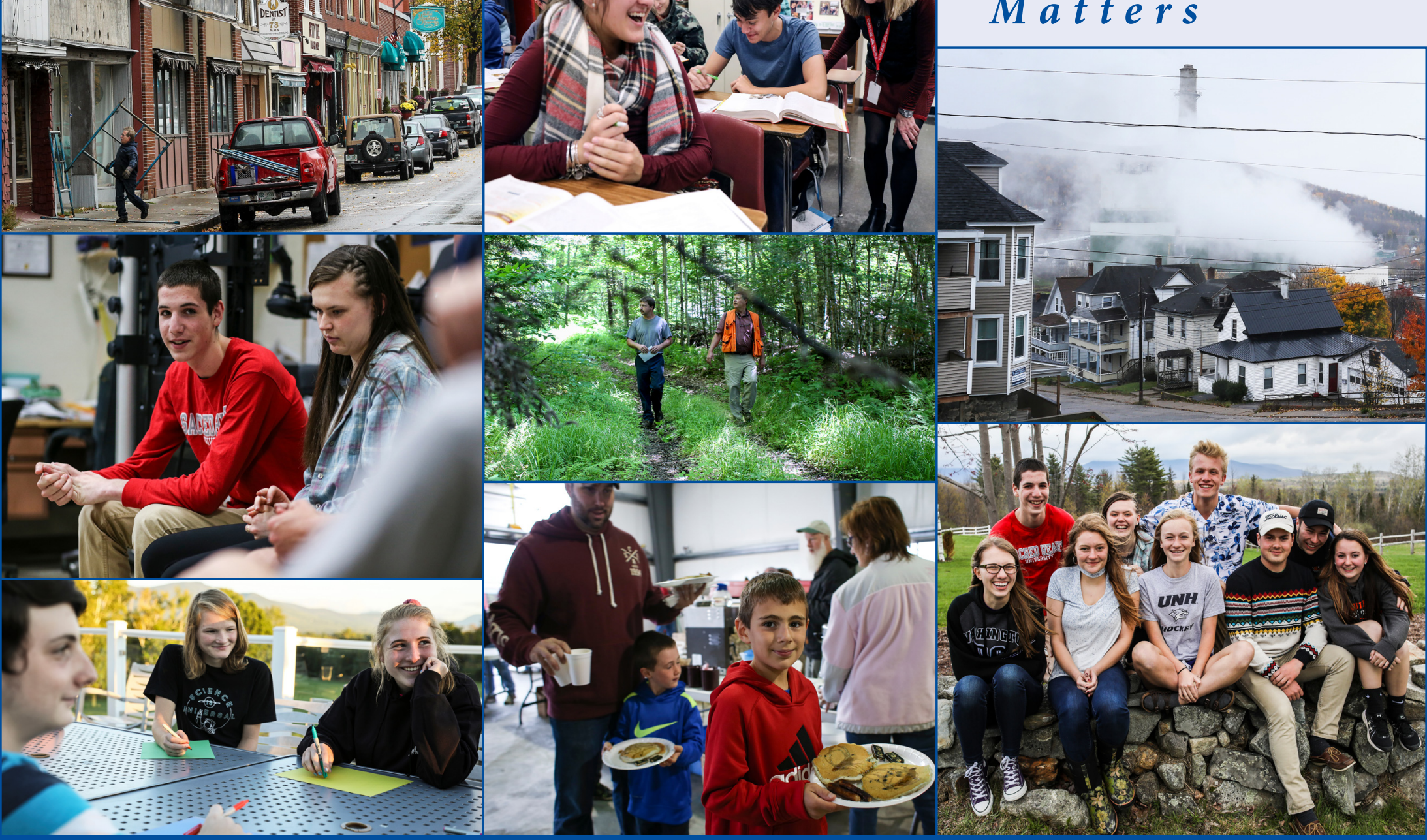

Northern New Hampshire Youth in a Changing Rural Economy A Ten-Year Perspective

ELEANOR M. JAFFEE CORINNA JENKINS TUCKER KAREN T. VAN GUNDY

University of New Hampshire

Carsey School of Public Policy
ERIN HILEY SHARP CESAR J. REBELLON 


\section{University of New Hampshire Carsey School of Public Policy}

\section{REPORTS ON NEW ENGLAND}

Number 5

This study was funded by a grant from the Neil and Louise Tillotson Fund of the New Hampshire Charitable Foundation. Additional funding was provided by the National Science Foundation (National Science Foundation Social and Economic Sciences Grant Award \#1155797).

Special thanks to Coös Youth Study participants and their families, Coös school administrative unit superintendents and principals, and Kirsten Scobie of the Neil and Louise Tillotson Fund of the New Hampshire Charitable Foundation, without whom this research would not have been possible.

Photos by Cheryl Senter. Used by permission of the New Hampshire Charitable Foundation.

(C) Copyright 2019

Carsey School of Public Policy University of New Hampshire Huddleston Hall

73 Main Street

Durham, New Hampshire 03824-3563

603-862-2821

carsey.unh.edu

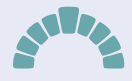

NEW HAMPSHIRE CHARITABLE FOUNDATION
The Neil \& Louise Tillotson Fund

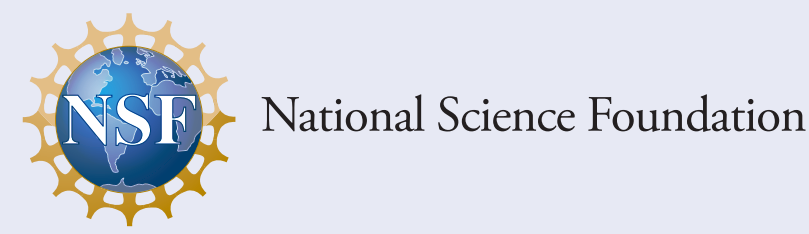




\title{
Northern New Hampshire Youth in a Changing Rural Economy A Ten-Year Perspective
}

\author{
Eleanor M. Jaffee \\ Project Manager \\ Corinna Jenkins Tucker \\ Co-PRINCIPAL INVESTIGATOR \\ Karen T. Van Gundy \\ Co-Principal InVESTIGATOR \\ ERIN Hiley Sharp \\ Co-Principal InVESTIGATOR \\ Cesar J. Rebellon \\ Co-PRINCIPAL INVESTIGATOR
}

A Carsey School of Public Policy Report on New England 


\section{Table of Contents}

\section{Foreword 5}

\section{Executive Summary 6}

Key Study Findings 6

\section{Introduction 8}

From a Manufacturing Past to an Uncertain Future 8

In the Present 9

2. Household Chaos and Adolescents' Future Plans, Parent-Child Relationships, and Well-Being 11

Household Chaos and Adolescents' Future Plans 11

Household Chaos and Adolescents' Parent-Child Relationships 12

Household Chaos and Adolescents' Well-Being 12

Conclusion 12

\section{Mental Health, Social Stress, and Sense of Community 13}

Co-Occurring Symptoms of Depression and Substance Misuse 14

Sense of Community 14

Sex, Stress, and Community 15

\section{Coös Youths' Future Aspirations, Expectations, and Attainment 17}

Coös Youths' Future Aspirations and Expectations Across Middle and High School 18

Future Aspirations and Expectations Subgroups 18

Do Future Aspirations and Expectations in High School Matter for Outcomes in Early Adulthood? 19

Residential Preferences in Early Adulthood 20

Predictors of High School Future Aspirations and Expectations 20

Implications 21

5. When We Foster a Sense of Community, Everybody Wins 23

6. Conclusion 27

Appendix: About the Coös Youth Study 28

About Coös Youth Study Participants 28

Where Are They Now? 29

\section{Endnotes 31}




\section{Foreword}

Y outh have been leaving rural communities for decades, and yet a vibrant future depends on young people staying or returning. Decades ago, young people who chose to work in natural resource-based industries or, in many places, manufacturing plants that had moved to rural areas to reduce labor costs, could stay and make a decent living and raise a family in a small-town environment. But in the last two to three decades those options have declined, and with lower-wage service sector jobs in retail, health, or tourism now dominant, the future for non-college bound youth looks increasingly dim. Northern New England is no exception, where communities are struggling to adapt to the loss of paper mill and other manufacturing jobs, and to the outmigration of young families the loss has caused. But communities in New Hampshire's North Country have a strong civic culture, a deep sense of community, and as this report demonstrates, that civic commitment is a strength that binds people to the community and a protective factor that supports the region's young people.

When the Neil and Louise Tillotson Fund of the New Hampshire Charitable Foundation was developed, its leaders made a long-term commitment to analysis to inform their grantmaking that aimed to build a new economy, steward the natural resources, and retain the strengths of the North Country communities. The Coös Youth Study-a ten-year panel study that followed over 800 young people from Coös County, New Hampshire-was a key part of that strategic commitment. Such an investment is highly unusual for a regional philanthropy, but the Tillotson Fund's leadership believed they could make better investment decisions if they knew more about the lives, choices, aspira- tions, and challenges facing the region's youth. How are young people affected by the changing economy? What influences their decisions to leave the region or stay, and what draws back those who return? What can we learn about the factors that protect and support youth from chaotic or disadvantaged families, and how can those factors be enhanced, especially in economically distressed times? How can North Country communities best support their young people and thereby build a new future?

Carsey researchers and their partners have learned much over the decade through this panel study. We know that there is a persistently strong sense of community, including trust and cooperation, and we know it matters. We know that teachers and mentors matter. And we know that both the sense of community and the support of caring adults make a difference for young people, including, importantly, for those in stressed and chaotic families.

In this report Corinna Jenkins Tucker brings her understanding of how household chaos hinders young people's future success as adults, noting that Coös youth experience less chaos than young people in other places, despite the economic changes in the region. Karen Van Gundy finds that the strong sense of community in Coös County protects young people who experience stress, reducing the risk of depression and substance misuse. Erin Hiley Sharp finds that young people with high aspirations do better, and those with lower confidence about their future face challenges transitioning to adulthood. They need adult support. Cesar Rebellon shows that young people with a stronger sense of community fare better in every way, and that overall Coös youth have a strong sense of community and this helps them succeed. He also identifies the important role played by youth voicewhen young people feel heard they may be more likely to stay connected to their community and return as adults.

Rural youth across America face challenges in today's economy. But time after time the researchers at the Carsey School have found that young people in Coös County, like the adults in their lives, have a strong connection and commitment to their community. This sense of community supports them as they make the transition to adulthood. Much research has shown that stable supportive families and mentors provide young people with the resources and confidence they need to succeed. The Coös Youth Study also demonstrates these key findings. But in Coös, with its strong civic culture and community bond and commitment, working to provide that support to vulnerable kids and their families is more likely and more possible, especially when it is combined with the generous, wise, and informed investment of the Tillotson Fund of the New Hampshire Charitable Foundation.

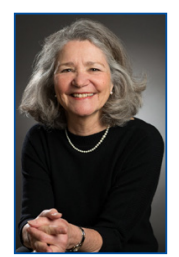

-Cynthia (Mil) Duncan, Professor Emerita, Sociology, and Carsey Senior Fellow, University of New Hampshire 


\section{Executive Summary}

$\mathrm{T}$ he Coös Youth Study was a ten-year research project about growing up in a rural county undergoing transformative economic and demographic changes. We were interested in how those changes factored into youths' plans to stay in the region, pursue opportunities elsewhere, permanently relocate, or return to their home communities with new skills and new ideas. From 2008 to 2018, we gathered data from 831 survey participants at up to six points in time.

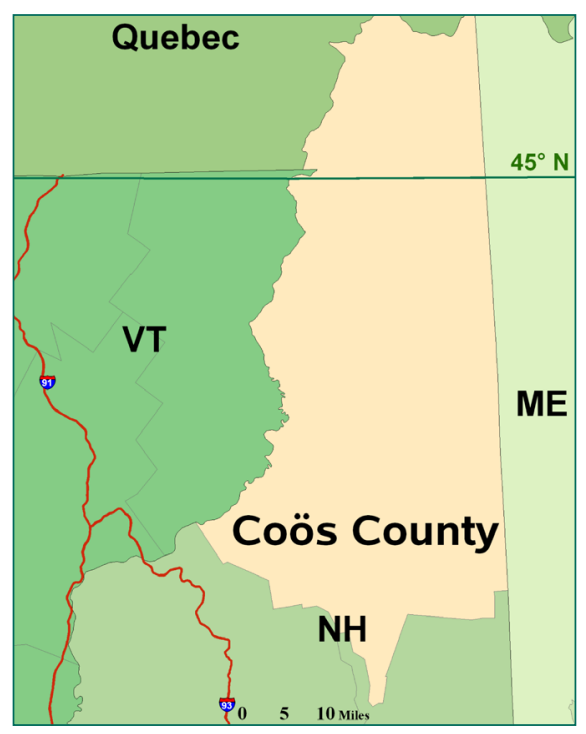

Located in northernmost New Hampshire, bordering Canada, Coös County enjoys an abundance of natural beauty and productive forest land. Pulp and paper mills served as the economic backbone of the region for generations. However, in the years leading up to the study, most of the mills closed in rapid succession, resulting in widespread job losses. The number of family households with children under 18 fell by almost a quarter in this period of manufacturing decline. ${ }^{1}$ The study was thus seen by stakeholders interested in rebuilding local economies and maintaining vibrant Coös communities as a timely opportunity to check in with the region's youth. The results point to specific areas for action to support and retain young people.

\section{Key Study Findings}

Key findings from our multidisciplinary research team span four broad topics regarding Coös youths' well-being and their decisions about the future.

Adolescents may not be able to change their home environments, but they can be shown skills to improve predictability and organization in their schoolwork and personal routines.

In the section "Household Chaos and Adolescents' Future Plans, ParentChild Relationships, and Well-Being," Corinna Jenkins Tucker reports:

- Chaotic home environments, characterized by lack of predictability, routine, organization, and stability, can happen at any socioeconomic level.

- Coös adolescents report lower levels of household chaos than reported in other U.S. studies.

- Household chaos is linked with adolescents having a more negative outlook on the future and lower mental and physical well-being.

Adolescents may not be able to change their home environments, but they can be shown skills to improve predictability and organization in their schoolwork and personal routines. Clinical and programmatic efforts could be designed to limit and prevent household chaos by supporting families in household management.
Sense of community is a powerful resource for Coös youth; policies and practices that promote the development and maintenance of community ties in youth can serve to reduce adult risk for adverse mental and behavioral health outcomes.

In the section "Mental Health, Social Stress, and Sense of Community", Karen T. Van Gundy finds that community attachment may reduce the risk of developing co-occurring symptoms of depressed mood and substance misuse-symptoms to which a 2011 Coös Youth Study report found that study participants were four times more susceptible than their nationwide counterparts. Among other findings:

- Young women who reported high stress in youth were more likely to report co-occurring symptoms of depressed mood and substance misuse in adulthood.

- A strong sense of community in youth was related to a lower risk for co-occurring symptoms of depressed mood and substance misuse in adulthood, for both women and men, even when accounting for youth depression, substance misuse, and stressful life events.

Even youth who do not show signs of depression are likely to reap long-term benefits from strategies that help them find healthy ways to cope with stress early in life. Programs that emphasize stress management in youth may be particularly important for Coös women's long-term health and well-being. Sense of community is a powerful resource for Coös youth; policies and practices that promote the development and maintenance of community ties in youth can serve to reduce adult risk for adverse mental and behavioral health outcomes. 
Increasing efforts to identify and support students who are struggling academically and who are disconnected from their school or community as early as possible could significantly improve these students' future aspirations, expectations, and attainment.

In the section "Coös Youths' Future Aspirations, Expectations, and Attainment," Erin Hiley Sharp looks at participants' educational and career outcomes and finds:

- Most high school students in Coös reported high aspirations and expectations for the future, but in general they were more confident about graduating from high school and finishing college than having a successful career.

- On average, Coös boys were less confident than Coös girls about their futures in terms of both education and career success, and, as a group, they were less likely to be enrolled in school full time in early adulthood.

- High school students who felt most confident in their ability to succeed in their future education and career pursuits were the least likely to report two years post-high school that they planned to make their future home in Coös.

Increasing efforts to identify and support students who are struggling academically and who are disconnected from their school or community as early as possible could significantly improve these students' future aspirations, expectations, and attainment. Investment by schools and communities in opportunities for non-college-bound youth to explore careers and prepare for

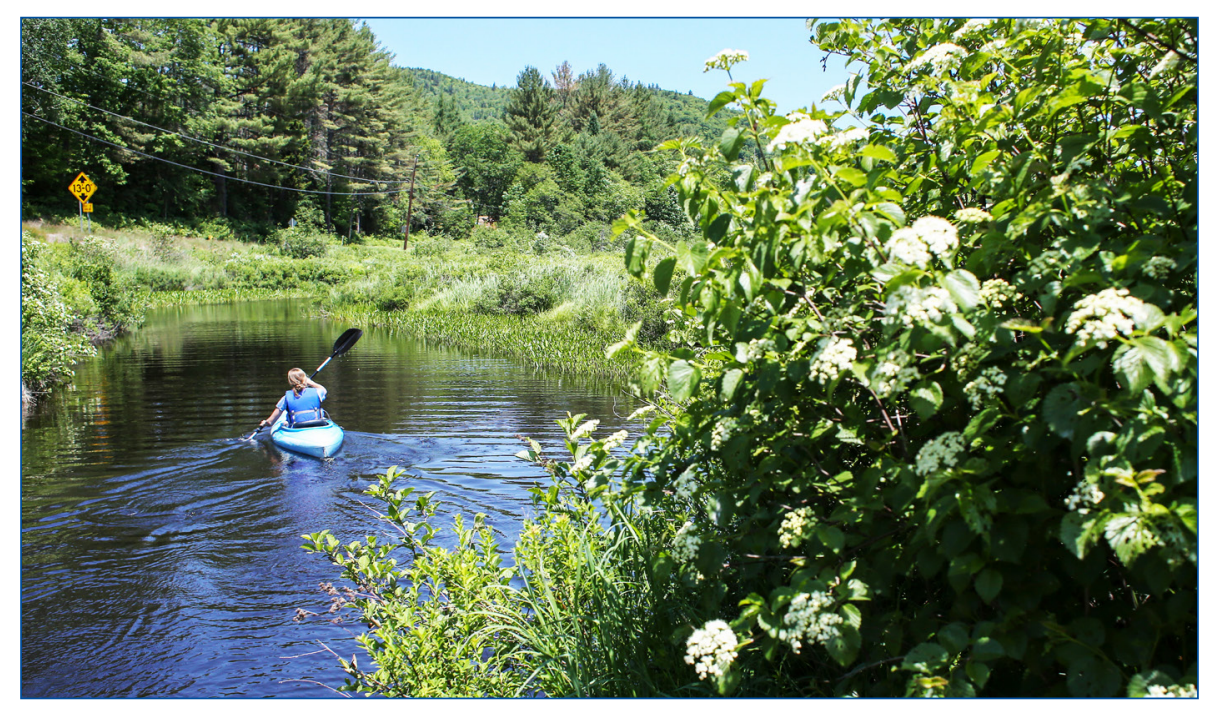

the workforce could also benefit Coös young people and enhance the vitality of the region. Efforts are needed to help all Coös young people see a clearer role for themselves in the region's existing economy, and this seems particularly important for boys.

It is important that adults in Coös County continue to foster a sense of community among youth and do more to convince youth that their concerns and opinions matter to adults.

In the section "When We Foster a Sense of Community, Everybody Wins," Cesar J. Rebellon describes how community attachment during youth relates to future outcomes, including decisions about where to live as an adult.

- Youth who feel like their voices are heard during childhood and adolescence may be more prone to desire a long-term future in Coös even if they leave for a while during early adulthood to pursue educational or professional opportunities elsewhere.
- The sense of community among Coös youth is strong and remained resilient in the face of the Great Recession. The exception is youth voice, which remained low in comparison to school belonging, community integration, and community support.

It is important that adults in Coös County continue to foster a sense of community among youth and do more to convince youth that their concerns and opinions matter to adults. While it will be healthy for some youth to leave Coös County to pursue educational or professional goals, enticing some to return someday may involve more than jobs or economic development. 


\title{
1. Introduction
}

\author{
Eleanor M. Jaffee
}

$\mathrm{I}$ 2008, we embarked on a decadelong study of young people ages 13 and 17 living in Coös County, New Hampshire. We were interested in knowing what it was like for them to grow up in a rural area undergoing transformative economic and demographic changes, and how those changes factored into their plans to stay in the region, pursue opportunities elsewhere, permanently relocate, or return to their home communities later on with new skills and experiences to share. Therefore, we set out to explore their beliefs, opinions, and aspirations for the future as they progressed through early adulthood. Eighty-three percent of all $7^{\text {th }}$ - and $11^{\text {th }}$-grade students enrolled in Coös County public schools participated in our first onsite paper and pencil surveys in 2008. Over the ten years of our study with these two cohorts, we have gathered data from a total of 831 participants-including those who have stayed in Coös County and those who have left-at up to six points in time.

\section{From a Manufacturing Past to an Uncertain Future}

Coös is the northernmost county in New Hampshire, stretching upward from the White Mountains to the Canadian border. It enjoys an abundance of natural beauty and productive forest land. Recent estimates place the total county population at about $31,600^{1}$ and the median household income at about $\$ 45,000$, compared to $\$ 55,000$ nationally. ${ }^{2}$ Its largest city, Berlin, is located approximately 180 miles north of Boston, Massachusetts (about four hours by car). Many residents in the towns "north of the notches," referring to the mountain highways that connect them to more populous points south, pride themselves on their ability

to work together and solve their own problems. The remote location coupled with the cold climate (January, the region's coldest month, has an average low temperature of 5 degrees and an average high temperature of 26 degrees Fahrenheit ${ }^{3}$ ) contribute to an ambient sense of the independent "live free or die" New Hampshire spirit. The mountain ranges are a constant backdrop along country roads dotted with small town centers, some well-maintained and others less so, that quickly give way to open spaces. National chain stores and restaurants are present, but rare. Berlin is somewhat of an exception to this tableau with a denser downtown area and an industrial outskirt illustrative of its prosperous manufacturing past and its current challenge in forging an economically viable path forward.

Relative to many other rural areas in the United States, Coös County has done well. It has maintained a solid middle class, stable investment in public health and education, broad participation in civic life, and a strong commitment to community that crosses the typical dividing lines of income and social status. Local arts and culture are celebrated in a busy year-round calendar of festivals, fairs, markets, and other events. ${ }^{4}$ Yet like many other rural areas, particularly those that thrived on manufacturing or agriculture and fisheries in the 20th century, it has experienced significant economic and demographic changes. 
Figure 1. Employment Sectors as a Percentage of All Jobs in Coös County, 2001-2016

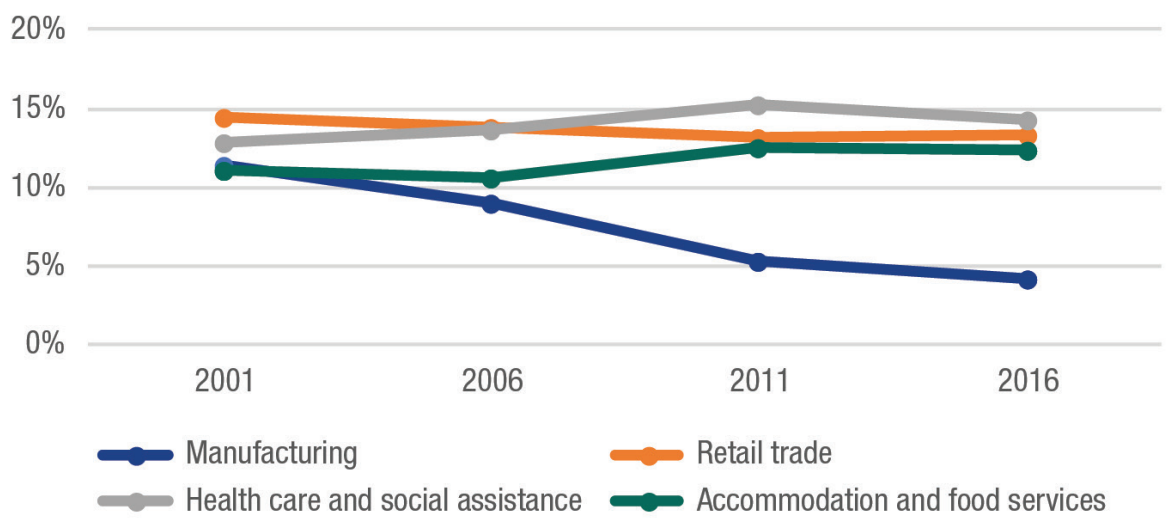

Source: Bureau of Economic Analysis

Pulp and paper mills served as the economic backbone of the region for generations. In the years leading up to the study, most remaining area mills closed their doors in rapid succession, primarily due to the outsourcing of the paper industry to China and other globalized sites. After multiple changes in name and ownership, Berlin's American Tissue pulp and paper mill closed in 2001, resulting in the loss of 800 jobs. It reopened under the ownership of Fraser Papers, but then closed again in 2006, and 250 jobs were lost. ${ }^{5}$ The Groveton Paperboard and Wausau Paper Corporation Mills in Groveton closed in 2006 and 2007, respectively, and another 411 jobs were lost. ${ }^{6}$ The Great Recession (2007-2009) reached into this distant corner of northern New England on the heels of the mill closures. The county unemployment rate pinballed from 3.6 percent in 2000 , to 6.6 percent in 2002 , to 4.1 percent by 2006 , and to 7.9 percent in 2009. ${ }^{7}$ Local families and communities struggled to adapt to the rapidly changing economic circumstances. A new biomass plant, a new federal prison, and tourism initiatives, including the opening of state park lands and downtowns to all-terrain vehicles, have since brought hope of reviving the regional economy. These developments have also at times stoked public controversy over how to balance economic development while preserving the region's natural amenities. ${ }^{8}$

The unemployment rate returned to an annual average of 3.4 percent in 2017. However, the number of jobs in Coös County had decreased by 9.4 percent between 2001 and 2016. As a percentage of the remaining jobs, the manufacturing sector took an especially big hit during this time, decreasing from 11.3 percent to 4.2 sectors in the county-retail trade, health care and social assistance, and accommodation and food serviceshave continued to dominate the local economy (Figure 1-1). ${ }^{9}$

Throughout this period of manufacturing decline, the population of young people in the county declined as well. From 2000 to 2017, the overall population fell by over 4 percent, from approximately 33,100 to 31,600 , but the population under 18 dropped by 31 percent, from about 7,500 to 5,200 ; at the same time, the population 65 and over rose by 20 percent, from about 6,100 to 7,300 . The number of family households with children under 18 declined by almost 24 percent, from about 3,900 to just under $3,000{ }^{10}$ percent. The other top employment
Furthermore, the estimated poverty rate among families with children under 18 increased from approximately 11 percent to 18 percent. ${ }^{11}$ These numbers suggest that many young families are opting to live elsewhere if they have the resources, a trend that may put the vision of community revitalization at risk.

The Coös Youth Study, planned in the late stages of the mill closures, was thus seen as a timely opportunity to understand the experiences of the county's youth during this period of transition, and to explore the factors involved in youths' decision-making. The results, as we elaborate in this report, point to specific areas for action to support and retain young people in Coös County.

\section{In the Present}

The sixth and final Coös Youth Study survey was conducted from October 2017 through March 2018, when the participants in the two cohorts were, on average, 22 and 26 years old. Overall, approximately 42 percent reported that they still lived in Coös County the majority of the time. The percentage of older cohort participants remaining in Coös has been declining since we began asking the question in 2011, the first survey after they graduated high school. That year 49 percent reported living in Coös County the majority of the time; by 2018, the share had fallen to 39 percent. However, whether participants reported that they resided in Coös or elsewhere, large majorities-89 percent and 78 percent, respectivelysaid that they still cared about issues and events in the county. 


\section{Box 2: Who Was Surveyed, and When}

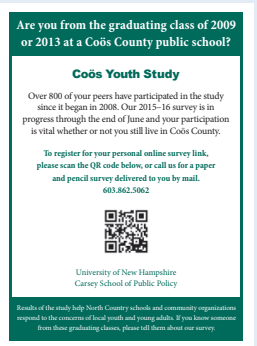

The Coös Youth Study was designed to follow two age groups or cohorts of youth into young adulthood by administering surveys at multiple points within a tenyear period. ${ }^{12}$ In the first survey, conducted in 2008 , all $7^{\text {th }}$ - and $11^{\text {th }}$-grade students at public schools in Coös County (the graduating classes of 2013 and 2009, respectively) were invited to participate. The $657 \mathrm{stu}-$ dents participating in the first survey represented 83 percent of all enrolled students in those grades that year. ${ }^{13}$ Ten years later, the response rate for both age cohorts, four and eight years out of high school, respectively, was 34 percent.

Long-term followup studies of rural youth are exceedingly rare. Tracking youth beyond high school through a developmental phase typically marked by major life transitions, as well as changes in residence and contact information, presents significant challenges. We are pleased that our substantial outreach efforts yielded a response rate comparable to, for example, the Pennsylvania Rural Youth Education Study (35 percent three years out of high school for a cohort recruited in $11^{\text {th }}$ grade). ${ }^{14}$ Table 1-1 details participation rates for each survey wave. For more information, see Appendix: About the Coös Youth Study.

Table 1-1. Coös Youth Study Survey Participation by Wave, Cohort, and Sex

\begin{tabular}{l|c|c|c|c|c|c}
\hline & $\begin{array}{c}\text { Wave I } \\
2008\end{array}$ & $\begin{array}{c}\text { Wave II } \\
2009\end{array}$ & $\begin{array}{c}\text { Wave III } \\
2011\end{array}$ & $\begin{array}{c}\text { Wave IV } \\
2013\end{array}$ & $\begin{array}{c}\text { Wave V } \\
2015-2016\end{array}$ & $\begin{array}{c}\text { Wave VI } \\
2017-2018\end{array}$ \\
\hline Male & 323 & 338 & 245 & 222 & 109 & 104 \\
\hline Female & 328 & 339 & 315 & 289 & 200 & 182 \\
\hline Sex not reported & 6 & 0 & 8 & 3 & 0 & 0 \\
\hline Younger cohort (YC) & 316 & 343 & 331 & 283 & 137 & 125 \\
\hline Older cohort (OC) & 341 & 334 & 237 & 231 & 172 & 161 \\
\hline Wave total & 657 & 677 & 568 & 514 & 309 & 286 \\
\hline YC response rate & $83 \%$ & $91 \%$ & $95 \%$ & $96 \%$ & $31 \%$ & $29 \%$ \\
\hline OC response rate & $83 \%$ & $85 \%$ & $60 \%$ & $58 \%$ & $43 \%$ & $40 \%$ \\
\hline Total response rate & $83 \%$ & $87 \%$ & -- & -- & $37 \%$ & $34 \%$ \\
\hline
\end{tabular}

Notes: 1) YC=younger cohort (class of 2013), $0 \mathrm{C}=0$ lder cohort (class of 2009). 2) Response rates for survey administrations in school (YC Waves I-IV, OC Waves I-II) use New Hampshire Department of Education enrollment numbers by cohort as the denominator. 3) Response rates for survey administrations after high school graduation (YC Waves V-VI, OC Waves III-VI) use the total number of participants recruited during school administrations by cohort as the denominator, as we only followed up with existing participants. 4) Total response rates not calculated for Waves III and IV because different denominators applied to the younger cohort (school enrollment) and older cohort (total recruited during school administrations).

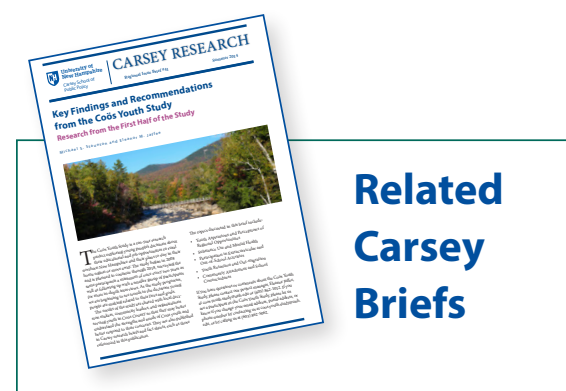

" Key Findings and Recommendations from the Coös Youth Study

»Coös County's Class of 2009: Where Are They Now?

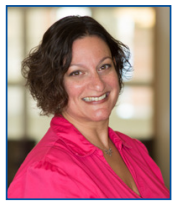

Eleanor M. Jaffee, $\mathrm{PhD}$, is a research assistant professor, the evaluation program director, and the Coös Youth Study project manager at the Carsey School of Public Policy at the University of New Hampshire (Eleanor.Jaffee@unh.edu). 


\title{
2. Household Chaos and Adolescents' Future Plans, Parent-Child Relationships, and Well-Being
}

\author{
Corinna Jenkins Tucker
}

$\mathrm{H}$

ousehold chaos occurs when a home environment at any socio-economic level lacks predictability, routine, organization, and stability. ${ }^{1}$ One might expect that, given that many Coös County parents must drive significant distances for steady, non-seasonal employment, ${ }^{2}$ providing organization, stability, and routine for their children and to be emotionally available and engage in positive parenting practices might be a struggle. However, though there are no national statistics on the frequency and extent of household chaos in the United States, on average Coös adolescents report lower mean levels of household chaos than what has been reported by parents and children in other studies across the United States. ${ }^{3}$

Household chaos was explored in one wave (2011) of the Coös Youth Study when members of the younger cohort were in mid-adolescence. Household chaos was measured by having the students rank the following six items on a scale of 0 (not true at all) to 4 (very true) for the past month:

I can't hear myself think where I live.

It is a real zoo where I live.

The atmosphere where I live is calm.

I am usually able to stay on top of things where I live.

I have a regular morning routine where I live.

There is usually a television turned on where I live.

The mean score was 1.39 , and average scores ranged from 0 to 3.50. ${ }^{4}$ Sixty-two percent of the adolescents scored 1 or higher on the measure.

\section{KEY FINDINGS}

» Adolescents recognize the chaos in their family lives.

» Coös adolescents report lower levels of household chaos than what has been reported in other U.S. studies.

» Households that lack routine, regularities, and rituals foster less adaptive functioning in adolescence.

» Household chaos is linked with adolescents having a more negative outlook on the future and lower mental and physical well-being.

\section{Household Chaos and Adolescents' Future Plans}

Adolescence is a time of identity exploration, and development during this period includes initial attempts at independent decision-making and the consideration of possible life directions. In chaotic households, adolescents' sense of the future and preparation for emerging adulthood may be limited by the disorganized and unpredictable nature of their home lives. In this context, adolescents may feel distracted and not able to focus on who they are and their future plans, leaving them feeling less certain of themselves. Also, household chaos may foster adolescents' sense of having a lack of control over their environments and facing obstacles in their futures. This is concerning because adolescents who do not feel competent and positive about the future may enter emerging adulthood without crucial personal resources to successfully transition through this developmental period.

With the Coös survey data, we explored how adolescents' reports of household chaos were linked to their sense of mastery (e.g., control over their lives, being able to do anything they set their minds to), beliefs about

\section{KEY IMPLICATIONS}

» Household chaos during this important developmental period may be a significant risk factor for poor life-long health.

» Adolescents may not be able to change their home environments, but they could be shown skills to improve predictability and organization in their schoolwork and personal routines.

» Clinical and programmatic efforts could be designed to limit and prevent household chaos by supporting families in household management.

future obstacles (e.g., having opportunities for future schooling), stress about transitioning to emerging adulthood and about their parents' ability to "let go," and perceptions of the likelihood they would have successful careers. As expected, Coös adolescents who experienced higher levels of household chaos reported a lower sense of mastery and less-positive expectations and beliefs about their futures. ${ }^{5}$ 


\section{Household Chaos and Adolescents' Parent-Child Relationships}

Household chaos is believed to interfere with consistent, positive parenting behaviors. In chaotic homes, parents' ability to appropriately respond is impaired as they struggle with selfregulation, responsiveness, and sensitivity. Such behavior leads to interactions of even lower quality in which parents are less available, more negative, ${ }^{6}$ and harsher ${ }^{7}$ to their children. In the Coös study, higher levels of household chaos were related to adolescents' reports of lower-quality relationships with their mothers and fathers. ${ }^{8}$

Chaos can directly influence the extent to which supportive and helpful developmentally appropriate interactions like support, advice, and consultation take place between parents and adolescents. ${ }^{9}$ In our study, adolescents in families with higher levels of household chaos and mother's hostility were more likely to perceive their families as an obstacle to their future plans and their parents as less likely to "let them go."10 Such hostility may leave adolescents wondering about their ability to successfully handle these family-related obstacles as they transition to becoming young adults and explore their futures.

\section{Household Chaos and Adolescents' Well-Being}

Adolescence is a critical time to develop the ability to regulate one's emotions and behaviors in preparation for becoming an autonomous adult. Stress related to household chaos impacts an individual's ability to regulate emotions and behaviors, ${ }^{11}$ and may leave adolescents feeling helpless and incompetent and put their physical and behavioral health at risk. Coös adolescents' perceptions of higher levels of household chaos in the $10^{\text {th }}$ grade were directly linked to reporting worse physical health (e.g., more illness, trouble sleeping) and problematic substance use (e.g., being under the influence of alcohol or drugs at school or work, reporting that they had accidentally hurt themselves while using alcohol or drugs) in $12^{\text {th }}$ grade. As noted, in chaotic homes parents often struggle with responsiveness and sensitivity leading to negative or harsh parenting. Analyses of Coös survey data showed that household chaos intensified the effect of hostile parenting in $10^{\text {th }}$ grade on adolescents' depressive symptoms two years later. ${ }^{12}$ Our work suggests that household chaos can directly affect mental health and intensify the effects of negative parenting on adolescents' well-being at a time when adolescents are likely considering important post-high school educational and occupational plans.

\section{Conclusion}

Coös adolescents recognize the "chaotic-ness" of their family lives. Although these youth perceive less household chaos than what has been reported in other studies, our data showed that households that lack routine, regularities, and rituals foster less adaptive functioning in adolescence. Specifically, our data demonstrated that household chaos is linked with adolescents having a more negative outlook on the future and lower mental and physical well-being. Adolescents from chaotic households may feel that little is under their control and see little hope they can have a successful transition to adulthood. Household chaos during this important developmental period may be a significant risk factor precluding successful life-long health.

No known prevention or intervention programs exist to reduce household chaos. However, while adolescents may not be able to change their home environments, they could be shown skills to improve predictability and organization in their schoolwork and personal routines. Schools play an important role in aiding adolescent well-being, and perhaps school support around academic skills could be extended to adolescents' home routines.
As suggested by the American Academy of Pediatrics, individual development is maximized in a non-chaotic family context. Clinical and programmatic efforts designed to limit and prevent household chaos by providing instrumental help with prioritizing chores and activities and limiting parent-adolescent hostility through the promotion of positive parenting practices would benefit adolescents' health, family relationships, and future outlooks.

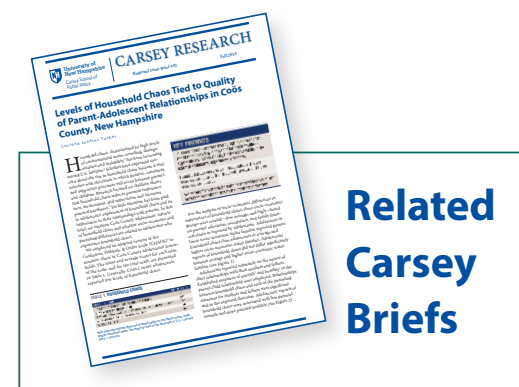

॥ Coös County Teens' Family Relationships

\Coös Teens' View of Family Economic Stress Is Tied to Quality of Relationships at Home

॥ Coös Youth with Mentors More Likely to Perceive Future Success ॥ Levels of Household Chaos Tied to Quality of Parent-Adolescent Relationships in Coös County, New Hampshire

» No Place Like Home: Place and Community Identity Among North Country Youth

॥ Sixty Percent of Coös Youth Report Having a Mentor in Their Lives

॥ Stay or Leave Coös County? Parents' Messages Matter

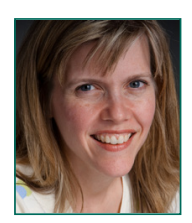

Corinna Jenkins Tucker, PhD, CFLE is a professor of human development and family studies at the University of New Hampshire and a faculty fellow at the Carsey School of Public Policy (c.j.tucker@unh.edu). 


\title{
3. Mental Health, Social Stress, and Sense of Community
}

\author{
Karen T. Van Gundy
}

$\mathrm{I}$

$\mathrm{n}$ recent years, depression has risen among American youth and young adults, ${ }^{1}$ and in New Hampshire, young-adult rates of depression and substance use disorder are among the highest in the nation. ${ }^{2}$ A report using data from the third wave of the Coös Youth Study (in 2011) found that respondents were more likely than their nationwide counterparts to report "frequently" or "almost all the time" at least one symptom of depression (e.g., "I felt sad") in the past 30 days. They also were more likely to report at least one symptom of substance use disorder (e.g., "I wanted to quit or cut down on my alcohol or drug use") in the previous year. Even more alarming, participants were four times more likely than their nationwide counterparts to report symptoms of both depressed mood and substance misuse at the same time. ${ }^{3}$ In 2015-17, 18 percent of the Coös Youth Study participants reported co-occurring symptoms of depression and substance misuse. Table 3-1 shows the most commonly reported symptoms.

\section{KEY FINDINGS}

» Young people in Coös County are committed to their communities.

» A strong sense of community in youth was related to a lower risk for co-occurring symptoms of depressed mood and substance misuse in adulthood for both women and men, even when accounting for youth depression, substance misuse, and stressful life events.

" Young women who reported high stress in youth were more likely to report co-occurring symptoms of depressed mood and substance misuse in adulthood.

» Adult risk for co-occurring symptoms of depression and substance misuse was elevated for respondents who reported both high levels of stress and relatively low depression in youth.

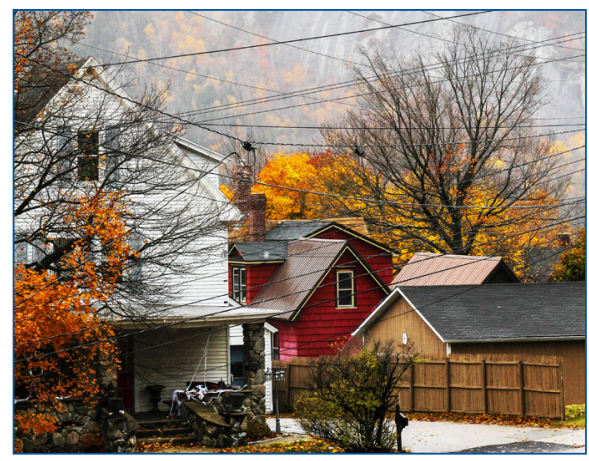

Table 3-1. Most Commonly Reported Symptoms of Depressed Mood and Substance Misuse in 2015-2017

\begin{tabular}{l|l}
\multicolumn{1}{c|}{ DEPRESSED MOOD SYMPTOMS } & \multicolumn{1}{c}{ SUBSTANCE MISUSE SYMPTOMS } \\
$\begin{array}{l}\text { In the past } \mathbf{3 0} \text { days... } \\
\text { I felt that everything I did was an effort (30\%). }\end{array}$ & $\begin{array}{l}\text { I wanted to quit or cut down on my alcohol or } \\
\text { drug use (41\%). } \\
\text { I used more alcohol or drugs than I meant to } \\
\text { use (28\%). }\end{array}$ \\
$\begin{array}{l}\text { I had trouble keeping my mind on what I was } \\
\text { doing (22\%). }\end{array}$ \\
$\begin{array}{l}\text { I could not get going (21\%). } \\
\text { my emotions or nerves (21\%). } \\
\text { I was under the influence of alcohol or drugs } \\
\text { when I could've gotten hurt physically (16\%). } \\
\text { I spent a lot of time getting over the effects of } \\
\text { alcohol or drug use (13\%). }\end{array}$ \\
\hline
\end{tabular}

Note: Presented are the five most commonly reported depressed mood symptoms "frequently" or "almost all the time" in the prior 30 days (out of 20 possible symptoms) and the five most commonly reported substance misuse symptoms in the prior 12 months (out of 15 possible symptoms).

\section{KEY IMPLICATIONS}

1) Sense of community is a powerful resource for Coös youth; policies and practices that promote the development and maintenance of community ties in youth can serve to reduce adult risk for adverse mental and behavioral health outcomes.

॥ Programs that emphasize stress management in youth may be particularly important for Coös women's long-term health and well-being.

»Stress in a young person matters. Even youth who do not show signs of depression are likely to reap long-term benefits from strategies that help them find healthy ways to cope with stress early in life. 


\section{Co-Occurring Symptoms of Depression and Substance Misuse}

Coös youths' perceptions and social experiences in 2008-2009-especially their exposure to social stressors and their views about their local communities-affected their adult risk in 2015-2017 for co-occurring symptoms of depression and substance misuse (henceforth "co-occurring symptoms"). Previous research has shown that the Coös study youth who reported more stressful life events (e.g., "Did a close friend or family member die?") tended to show higher levels of depression and substance misuse than those who reported fewer stressful life events. ${ }^{4}$ Girls tended to report more interpersonal stressors (e.g., "Did a close friendship end?"), and boys tended to report more physical violence (e.g., "Did anyone hit or attack you on purpose?"). ${ }^{5}$ Girls reported symptoms of depression more than boys, but the likelihood of substance misuse was essentially the same for boys and girls. Similarly, there were no sex differences in rates of co-occurring symptoms of depression and substance misuse. ${ }^{6}$

Experiencing depression early in life may be especially relevant for the long-term health and well-being of Coös youth relative to their peers in more urban contexts. A study that compared the Coös youth to youth from schools in two urban New Hampshire counties (Hillsborough and Strafford) found that, not only were rates of early depression (in 2008) higher among the $7^{\text {th }}$ - and $11^{\text {th }}$-graders in the study that year, but early depression was a stronger predictor of later substance misuse (in 2013) for the Coös participants. ${ }^{7}$ In fact, when controlling statistically for various factors, including early substance misuse and exposure to stress, early depression (in 2008) increased the odds of substance misuse (in 2013) only among the Coös participants. Our analyses here suggested a comparable pattern with respect to co-occurring symptoms; that is, for the Coös respondents only, high levels of youth depression in 2008 were associated with higher odds of co-occurring symptoms in 2013, even when we took into account a range of factors like early substance misuse, stress exposure, age, sex, and socioeconomic status.

Prior research has also shown that youths' sense of community is important for their emotional and behavioral health. For both Coös youth and their urban New Hampshire peers (from Hillsborough and Strafford counties), community attachment (e.g., "I live in a close-knit community") was associated with less substance misuse, and community detachment (e.g., "Once you get a bad reputation in this community, it's hard to get rid of it") was associated with increased risk for depressed mood and substance misuse. ${ }^{8}$ However, community attachment was related to lower depression risk among the Coös youth only. Moreover, higher community attachment in 2009 was related to lower rates of co-occurring depression and substance misuse symptoms in $2011 .{ }^{9}$

\section{Sense of Community}

A sense of community consists of both positive perceptions about one's local community (attachment) as well as negative views about one's community (detachment). In general, people living in rural areas, like Coös County, have tended to report higher levels of community attachment than their counterparts in nonrural areas. ${ }^{10}$ Similarly, when we compared the Coös youth to youth living in the urban Hillsborough and Strafford Counties, we found that the Coös youth scored higher on community attachment as well as on community detachment. ${ }^{11}$ This seemingly paradoxical finding highlights the unique significance of community ties-both the positive and negative aspects-for youth living in rural contexts. ${ }^{12}$ We examined here whether community attachment and community detachment among Coös youth in 2008-2009 affected their risk for co-occurring symptoms in adulthood in 2015-2017.

As Table 3-2 shows, Coös youth tended to feel a strong sense of attachment to their communities. Eighty-nine percent of respondents agreed that people in their communities were "caring, helpful, and friendly," 85 percent agreed that people were "willing to help their neighbors," and 82 percent agreed that people in their communities "can be trusted." Youth felt that their communities were safe $(84$ percent) and close-knit (73 percent). They were proud of their local communities (72 percent), enjoyed participating in community events (74 percent), and cared about ( 81 percent) and felt like part of (73 percent) their communities.

Yet, only about half of respondents (52 percent) agreed that "People in this community care what kids think," and many also agreed with statements reflecting a sense of detachment from the community. They felt bored ( 85 percent) and cut off from other communities (57 percent), and that the population was too small (66 percent). They felt that people in their communities judged others unfairly (71 percent), liked to gossip (90 percent), and "know too much about other people's business" (83 percent). Still, only half of the Coös study respondents agreed that people in their communities were rude (50 percent), and only about a quarter agreed that people in their communities did not get along (26 percent) or did not share the same values ( 26 percent). 
Table 3-2. Sense of Community in 2008-2009

\begin{tabular}{|l|l|}
\multicolumn{1}{|c|}{ COMMUNITY ATTACHMENT } & \multicolumn{1}{c|}{ COMMUNITY DETACHMENT } \\
\hline $\begin{array}{l}\text { My community has caring, friendly, helpful } \\
\text { people (89\%). }\end{array}$ & People in this community like to gossip (90\%). \\
\hline $\begin{array}{l}\text { People around here are willing to help their } \\
\text { neighbors (85\%). }\end{array}$ & $\begin{array}{l}\text { There are not enough different kinds of shops } \\
\text { or stores (90\%). }\end{array}$ \\
\hline My community is safe (84\%). & There is nothing to do here-it's boring (85\%). \\
\hline $\begin{array}{l}\text { People in this community can be trusted } \\
\text { (82\%). }\end{array}$ & $\begin{array}{l}\text { People in this community know too much } \\
\text { about other people's business (83\%). }\end{array}$ \\
\hline I care about my community (81\%). & $\begin{array}{l}\text { People in this community judge others } \\
\text { unfairly (71\%). }\end{array}$ \\
\hline $\begin{array}{l}\text { I am happy to participate in community } \\
\text { events (74\%). }\end{array}$ & The population here is too small (66\%). \\
\hline I feel like part of my community (73\%). & $\begin{array}{l}\text { My community feels like it's cut off from other } \\
\text { communities (57\%). }\end{array}$ \\
\hline This is a close-knit community (73\%). & People around here are rude (50\%). \\
\hline $\begin{array}{l}\text { I am proud to present my community to } \\
\text { people (72\%). }\end{array}$ & $\begin{array}{l}\text { People in this community do not share the } \\
\text { same values (26\%). }\end{array}$ \\
\hline $\begin{array}{l}\text { People in this community care what kids think } \\
\text { (52\%). }\end{array}$ & $\begin{array}{l}\text { People in this community do not get along } \\
\text { with each other (26\%). }\end{array}$ \\
\hline
\end{tabular}

Note: Presented are the percentages of youth who reported they "agree" or "agree strongly" with each item.

Previous Coös Youth Study research has shown that, not only is community attachment associated with lower substance misuse, but it can mitigate or buffer the harmful effects of stress exposure; that is, even among the most "stressed out" Coös youth, positive feelings about their communities (e.g., "I care about my community") offset their risk for substance misuse. ${ }^{13}$ Among girls with high stress levels in 2008, those who cared about their communities were half as likely as those who did not care about their communities to report substance misuse in 2009. "Stressed out" boys who did not care about their communities in 2008 were nearly four times more likely than those who cared about their communities to report substance misuse in 2009. Similarly, prior work has shown that community attachment buffered the harmful effects of social stress in 2009 on co-occurring symptoms in 2011 among the Coös participants. ${ }^{14}$

\section{Sex, Stress, and Community ${ }^{15}$}

Although there were no observed sex differences in co-occurring symptoms in 2015-2017, we were interested in whether or not there were sex differences in how early predictors, such as depression, stress exposure, and sense of community in 2008-2009 combined to affect cooccurring symptoms in adulthood in 2015-2017. We found that the effect of youth stress in 2008-2009 on adult co-occurring symptoms in 2015-2017 varied by sex. That is, for Coös women, the more stressful life events they reported in youth, the higher were their odds of reporting co-occurring symptoms of depression and substance misuse as adults; for young Coös men, however, youth stress was not associated with cooccurring symptoms of depressed mood and substance misuse in adulthood. This suggests that strategies that promote youth management of
Most notably, a strong sense of community was shown to be vital for the emotional and behavioral health of both the men and women in the Coös Youth Study.

social stress may be especially important for women's long-term health and well-being.

We then looked to see if youth who reported a high number of stressful life events in 2008-2009 (e.g., five or more of 19 possible events) were more likely to report co-occurring symptoms in 2015-2017, and we looked to see if the effects of stress were similar (or different) for depressed (versus non-depressed) youth. We were surprised to discover that high stress did not increase adult risk for co-occurring symptoms among those who reported the highest levels of depression in youth. This result may be due partly to a tendency for the most troubled youth (e.g., those with the highest levels of youth stress and depression) to drop out of the study-in 2015-2017, only 19 percent of included participants reported five or more stressful life events, and only about a quarter reported high levels of depressed mood in youth. Notably, we found that for less-depressed youth (the majority of the sample), early stress increased their risk for co-occurring symptoms in adulthood. These findings suggest that even youth who do not show signs of depression are likely to reap longterm health benefits from prevention strategies that help them cope with stressors early in life.

Most notably, a strong sense of community was shown to be vital for the emotional and behavioral health of both the men and women in the Coös Youth Study. A strong sense of community in youth (high attachment and 
low detachment) reduced the odds of co-occurring symptoms in adulthood regardless of sex. Other findings showed that co-occurring symptoms were lower for respondents who were parents. Even with statistical controls for parenthood and other potentially confounding factors such as employment status and educational attainment, youth's sense of community (high attachment and low detachment) strongly reduced their odds of reporting co-occurring symptoms of depression and substance misuse in adulthood. This finding underscores the critical importance of community context and connection for the health and well-being of youth and adults in Coös County. Given recent declines in the young-adult population in rural areas like Coös, regional activities, clubs, and school-sponsored programs-programs that pull people together from different towns and communities - could help to facilitate and enhance community cohesion among youth and adults in northern New Hampshire.
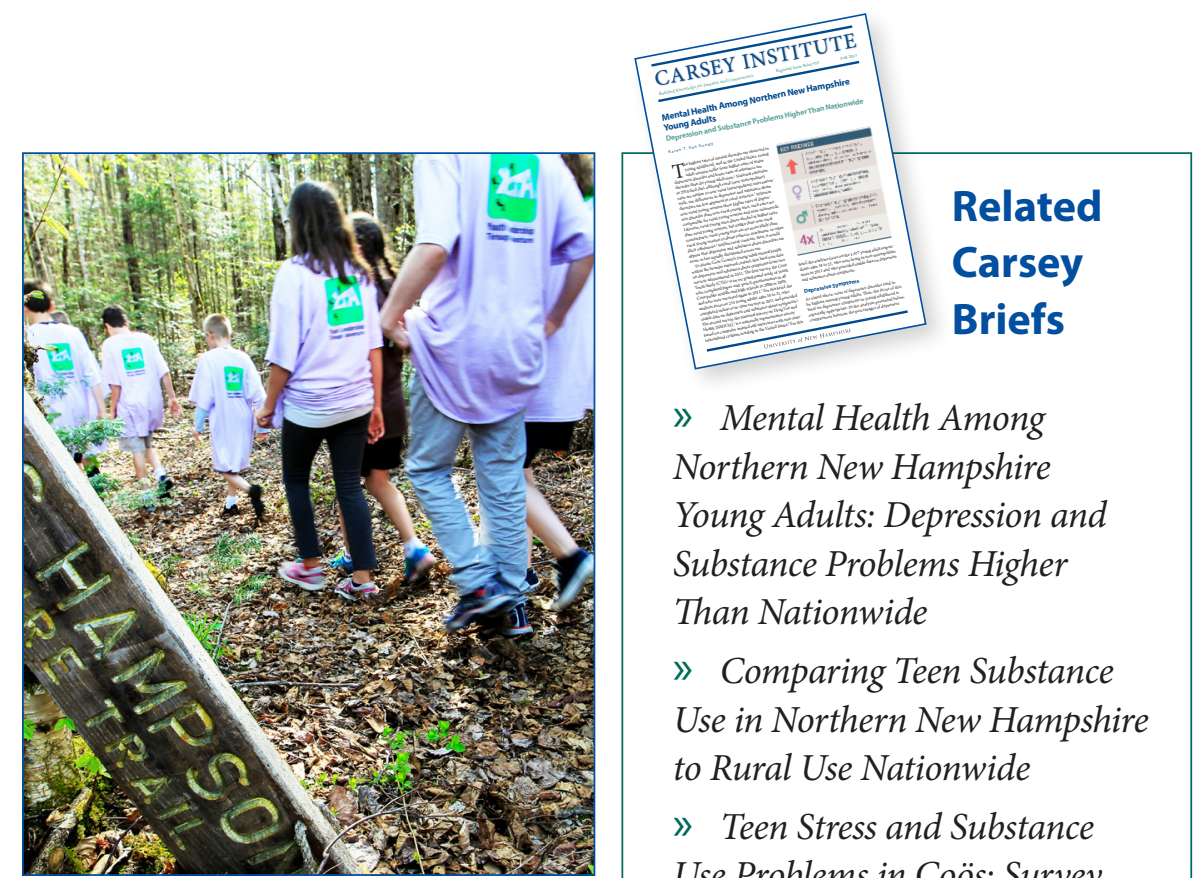

» Mental Health Among Northern New Hampshire Young Adults: Depression and Substance Problems Higher Than Nationwide

" Comparing Teen Substance Use in Northern New Hampshire to Rural Use Nationwide

» Teen Stress and Substance Use Problems in Coös: Survey Shows Strong Community Attachment Can Offset Risk

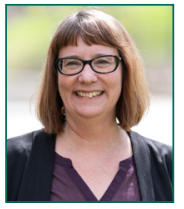

Karen T. Van Gundy, $\mathrm{PhD}$, is a professor of sociology at the University of New Hampshire and a faculty fellow at the Carsey School of Public Policy (Karen.VanGundy@unh.edu). 


\title{
4. Coös Youths' Future Aspirations, Expectations, and Attainment
}

\author{
Erin Hiley Sharp
}

$\mathrm{A}$ dolescence is the time when young people begin preparing for their transition to adult roles and responsibilities, and adolescents are asked more and more to make decisions that require future-oriented thinking. These include decisions such as what elective classes to take, whether or not to join certain extracurricular activities, whether or not to pursue higher education, and what type of work to seek. Adolescents' families, schools, and communities help inform these decisions as adolescents learn more about their interests, abilities, and the availability of opportunities.

The Coös Youth Study is one of a handful of studies nationally that addresses questions about how the sociocultural context of rural young people shapes how they think about, feel about, and plan for their futures and how this future-oriented thinking in high school links to outcomes in early adulthood.

A unique strength of the Coös Youth Study is that it tracked two distinct dimensions of young peoples' future-oriented thinking: future aspirations and future expectations. Future aspirations describe the level of hopefulness one has about accomplishing a specific goal or the importance one gives to accomplishing a goal, while future expectations describe one's estimation of the likelihood of actually reaching that future goal. We are able to examine how a match or mismatch between aspirations and expectations leads to different outcomes for young people in Coös. For example, an adolescent may aspire to graduate from college, but have little confidence that this goal will actually be achieved.

\section{KEY FINDINGS}

1) Most high school students in Coös County reported high aspirations and expectations for the future, but in general they were more confident about graduating from high school and finishing college than about having a successful career.

» High school students with the highest aspirations and expectations for future success were the most likely to be enrolled full time in higher education two years after high school.

॥ On average, Coös boys were less confident than Coös girls about their futures in terms of both education and career success, and, as a group, they were also less likely to be enrolled in school full time in early adulthood.

》 High school students who felt most confident in their ability to succeed in their future education and career pursuits were also the least likely to report two years after high school that they planned to make their future home in Coös.

Another strength of our study is that Coös youth answered questions about their future aspirations and expectations for both education and career. We were interested in better understanding adolescents whose future goals and plans may not include higher education. While close to 70 percent of all high school graduates in the United States enroll in college, the share for rural high school students is 59 percent. ${ }^{1}$ Nationally, only 29 percent of rural young adults age 18 to 24 are enrolled in higher education, and only about 18 percent of Coös County residents have obtained a bachelor's degree or higher. ${ }^{2}$ Thus, it is especially important to understand the aspirations and expectations of those young people who do not plan to pursue higher education.

\section{KEY IMPLICATIONS}

» Increasing efforts as early as possible to identify and support those students struggling academically and who are disconnected from their school or community could significantly improve their future aspirations, expectations, and attainment.

» Investment by schools and communities in opportunities for non-college-bound youth to explore careers and prepare for the workforce could benefit Coös young people and enhance the vitality of the region as a whole.

» Efforts are needed to help Coös young people see a clear and successful role for themselves in the existing economy in the region, and this seems particularly important for boys. 


\section{Coös Youths' Future Aspirations and Expectations Across Middle and High School}

Figures 4-1 and 4-2 show the percentage of Coös youth who reported having future aspirations and expectations at the highest possible level. The percentages presented were measured over time as the participants moved through the $8^{\text {th }}, 10^{\text {th }}$, and $12^{\text {th }}$ grades. Similar to other adolescents in the United States, Coös youth reported high aspirations for their futures (Figure 4-1). ${ }^{3}$ For many adolescents, their aspirations might be considered unrealistically high once factors like how well they are performing in school are taken into account. By contrast, future expectations are typically a bit lower and better illustrate realistic thinking. ${ }^{4}$ Coös young people were more confident in their ability to complete high school and finish college than to have a successful career (Figure 4-2).

Sex differences in future aspirations and expectations. Male students in Coös reported lower future aspirations and lower confidence in their ability to reach their future goals compared to their female peers. For example, the percentage of females in $12^{\text {th }}$ grade reporting the highest degree of confidence in finishing college was 79 percent, compared with only 55 percent of male students. Nationally, research on understanding how sex impacts adolescents' future aspirations, expectations, and attainment varies, with some studies finding no differences by sex, ${ }^{5}$ some studies finding that girls are more optimistic and confident about their futures, ${ }^{6}$ and others finding that boys are at an advantage in terms of future orientation. ${ }^{7}$ Sex may function differently in rural communities, with boys thought to benefit from more traditional gender role expectations and a perception of greater job availability in male-dominated sectors like agriculture and manufacturing. ${ }^{8}$ It is true that in Coös the high-paying jobs

Figure 4-1. How important is it for you to...? Percentage of youth reporting "very important"

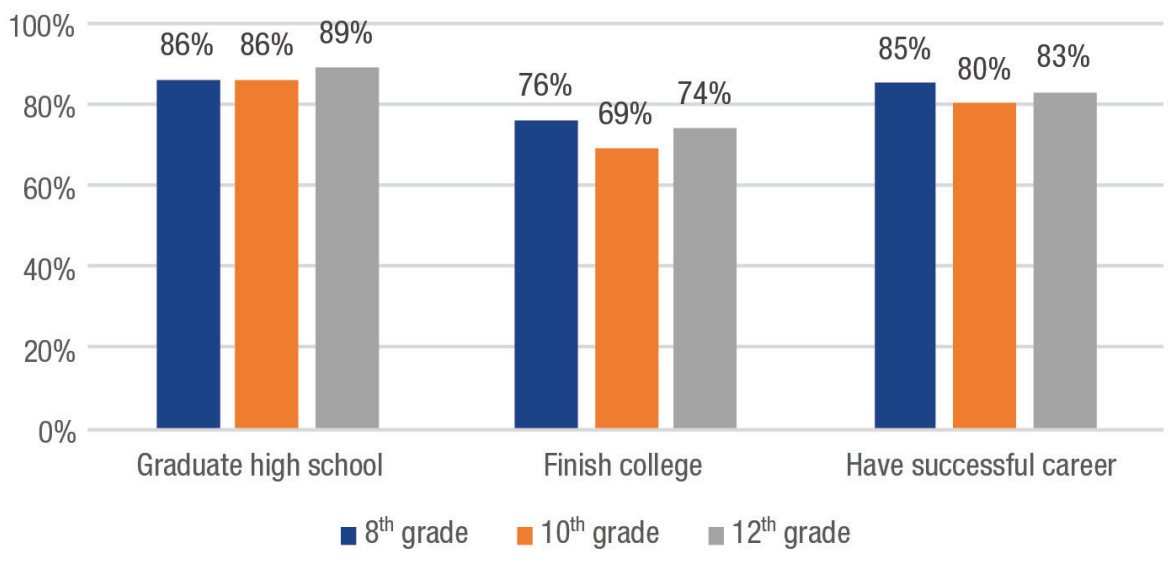

Source: Coös Youth Study Data

Figure 4-2. How likely is it that you will...? Percentage of youth reporting "very likely"

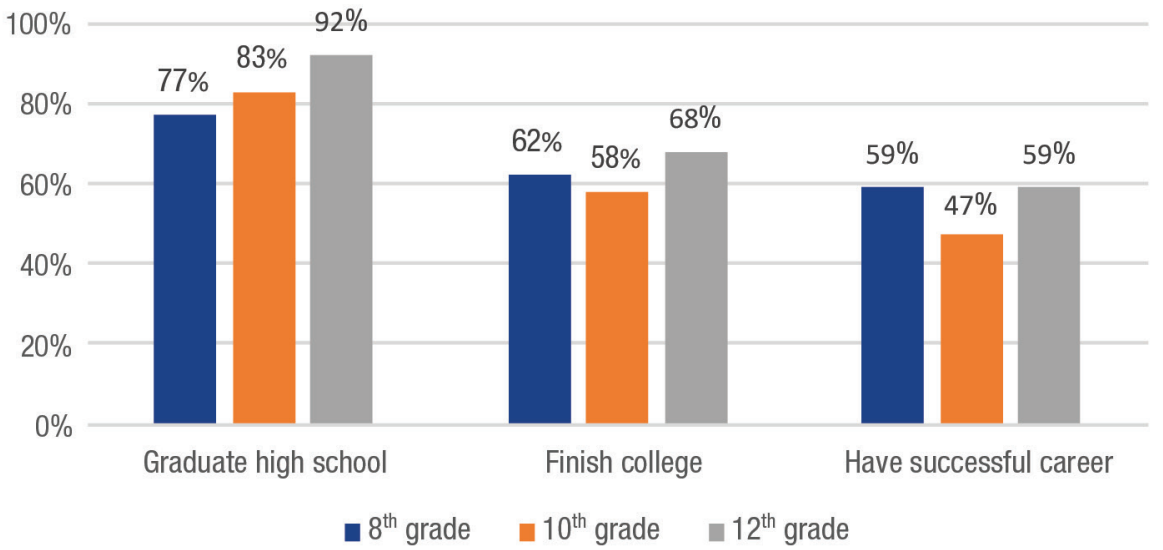

Source: Coös Youth Study Data

in pulp and paper manufacturing were male-dominated; however, the current economic engines in the county are in more stereotypically female fields like education, health care, and social services. Our findings suggest that these economic transitions are impacting how adolescents visualize their future opportunities.

\section{Future Aspirations and Expectations Subgroups}

Combining responses from both student cohorts included in the Coös Youth Study at the $12^{\text {th }}$-grade data collection, we identified subgroups of students who shared similar patterns of responses across the six future aspira- tions and expectations items measured (Figure 4-3). We identified four distinct subgroups of Coös youth who answered the future aspirations and expectations items in similar ways:

1. Universally high: highest aspirations and expectations across education completion and career success

2. Low college: higher aspirations and expectations regarding high school completion and having a successful career coupled with lower aspirations and expectations about college completion

3. Higher aspirations than expectations: aspire to more in their future in terms of education and career than they expect to reach 


\section{Figure 4-3. Future Aspirations and Expectations Among Coös Youth}

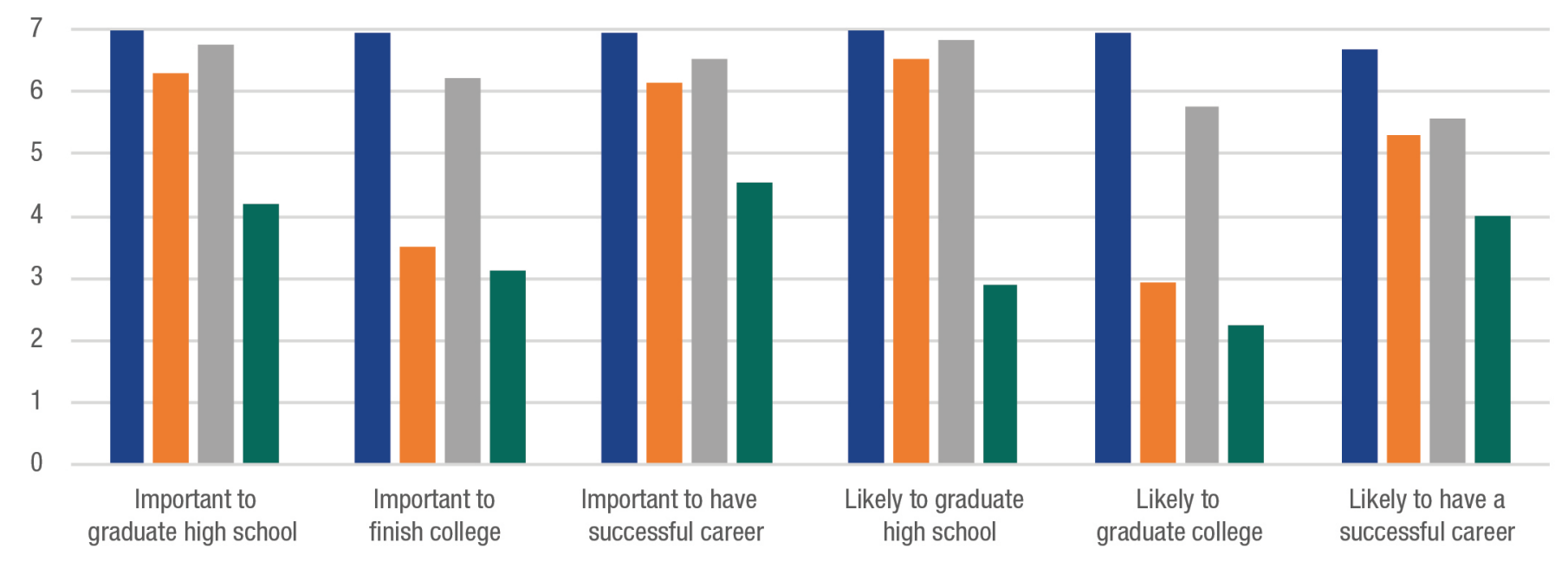

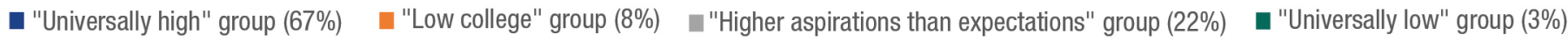

Note: The value on the $x$-axis represents the participants' responses to each of the future aspiration and future expectations items. Scores on the future aspiration items ranged from $1=$ not at all important to $7=$ very important, and scores on the future expectation items ranged from $1=$ very unlikely to $7=$ very likely. Source: Coös Youth Study Data.

4. Universally low: lowest aspirations and expectations across education completion and career success

Grouping the students in this way allowed us to study whether there were meaningful differences in the earlier high school experiences and the early adulthood outcomes linked to Coös youths' future aspirations and expectations in the $12^{\text {th }}$ grade.

Sex differences in subgroups. Once we identified these subgroups of Coös youth based on their future aspirations and expectations during their $12^{\text {th }}$-grade year, we found that male and female students differed in important ways in terms of their likelihood of being included in each of the four subgroups (universally high, low college, higher aspirations than expectations, and universally low). These sex differences are shown in Figure 4-4. Female Coös students in the $12^{\text {th }}$ grade were more likely to hold the highest aspirations and expectations about their future education and career success, while male students were more likely
Figure 4-4. Sex Differences in Future Orientation Subgroups

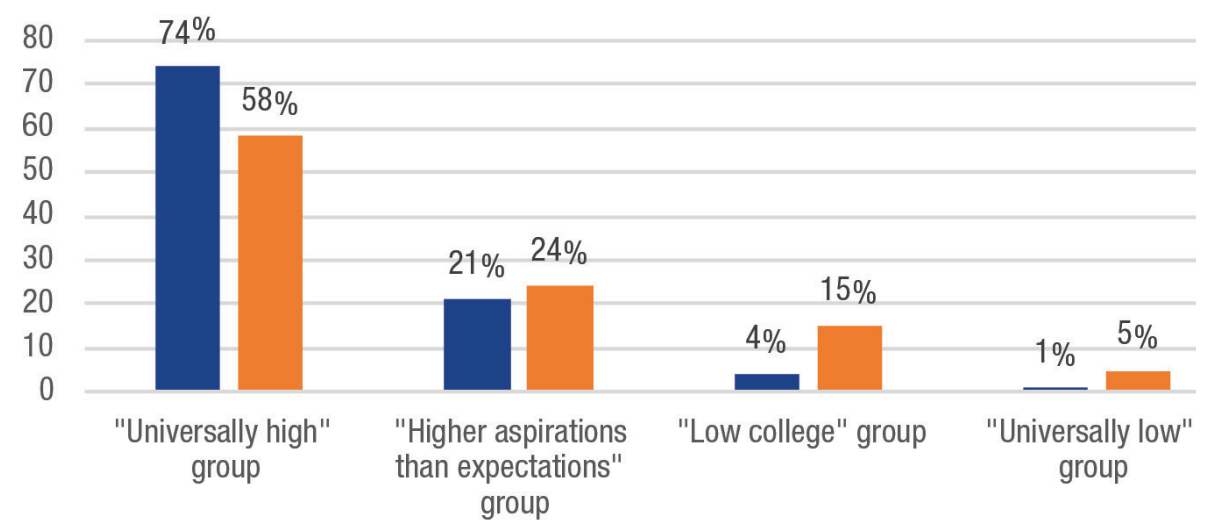

- Female 12th graders

Male 12th graders

Source: Coös Youth Study Data

to hold the lowest aspirations and expectations about their future success. Coös boys were also more likely to struggle to see college completion as something that was in their future even when feeling fairly positive about high school completion and a successful career. Overall, boys in Coös appear to have more difficulties envisioning success in their futures.

\section{Do Future Aspirations and Expectations in High School Matter for Outcomes in Early Adulthood?}

Learning more about young people's future aspirations and expectations is valuable only if these high school perceptions matter for adult outcomes. Previous studies with national samples report moderate to strong links between adolescents' future aspirations and expectations 
Figure 4-5. Percentage of Young Adults Who Plan to Live in Coös in the Future by Future Orientation Subgroups

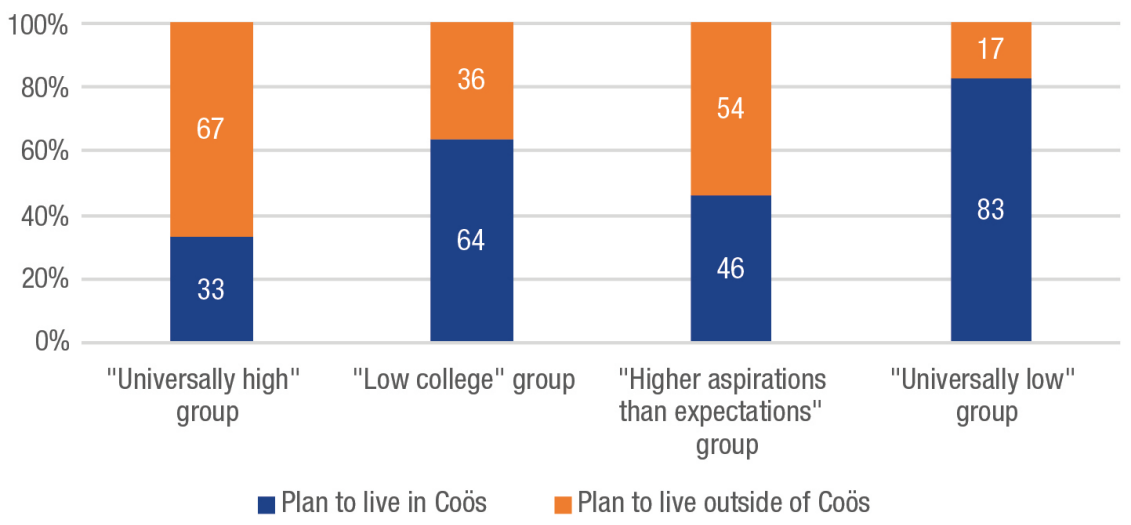

Source: Coös Youth Study Data

and their attainment of goals in early adulthood. ${ }^{9}$ However, few longitudinal studies exist in general, and even fewer with a rural focus. We looked at how Coös youths' future aspirations and expectations in $12^{\text {th }}$ grade linked to two outcomes in early adulthood (two years after high school): (1) education and employment status, and (2) future residential preferences.

Two years after high school, we asked participants about their current education and work status. We combined responses into four groupings: not working or in school (8 percent of participants), working and/or in school part time (10 percent of participants), primarily working full time (23 percent of participants), and primarily in school full time (59 percent of participants).

Seventy-four percent of the $12^{\text {th }}$ graders whose future aspirations and expectations about education and career were universally high reported being in school full time two years after high school. By contrast, only 7 percent of those in the low college and 0 percent of those in the universally low subgroups in $12^{\text {th }}$ grade were in school full time two years after high school. Fifty percent of Coös youth in the universally low subgroup in $12^{\text {th }}$ grade reported that they were not in school or working at this time in early adulthood compared to only 4 percent of those in the universally high group. Comparatively, 20 percent of those in the low college group and 9 percent of those in the higher aspirations than expectations group reported not being in school or working in early adulthood. Although the universally low group was relatively small, it appears to be a particularly vulnerable group struggling with the transition to adulthood.

\section{Males were more vulnerable than} females. Even the male $12^{\text {th }}$-grade students in the universally high subgroup, who reported the highest levels of future aspirations and expectations, were less likely than their female counterparts to be in school full time in early adulthood. More concerning is that the universally low subgroup was made up almost exclusively of boys, and 50 percent of those youth were not working or in school as young adults.

\section{Residential Preferences in Early Adulthood}

Rural community vitality depends, in part, on retaining and attracting a vibrant, young adult population. Coös continues to be affected by the outmigration of young people. Research suggests that often the young people who are most likely to leave rural communities are those who are better educated and more highly trained. ${ }^{10}$ Other work suggests that some highambition rural high school students aspire to leave their home communities but to return later in adulthood. ${ }^{11}$ We looked at whether there were meaningful differences in Coös Youth Study participants' responses, two years after high school, to the question, "Where do you plan to live the majority of the time?" based on their future aspirations and expectations in the $12^{\text {th }}$ grade (see Figure 4-5).

Responding two years after completing high school, only 33 percent of Coös young people with the highest future aspirations and expectations for education and careers success in the $12^{\text {th }}$ grade reported expecting to live the majority of their time, in the future, in Coös. This compares to 83 percent of the young people who were in the universally low future orientation subgroup in the $12^{\text {th }}$ grade who plan to make their futures in Coös. These perspectives may change significantly as these young people get older, complete education, and begin to make decisions about their family lives, but it is important to consider the implications of these findings for the region.

\section{Predictors of High School Future Aspirations and Expectations}

Given that the future aspirations and expectations of Coös young people in high school matter for outcomes in adulthood, we looked for specific individual and contextual factors during high school that may promote young people's future orientation. We looked at the following measures collected from study participants either in the $10^{\text {th }}$ or $11^{\text {th }}$ grade: self-esteem, sense of mastery over one's environment, parents' level of education, students' perception of their parents' aspirations for them, grades, sense of school belonging, and attachment to community. 
Figure 4-6. Early High School Predictors of $12^{\text {th }}$-Graders Future Orientation Subgroups

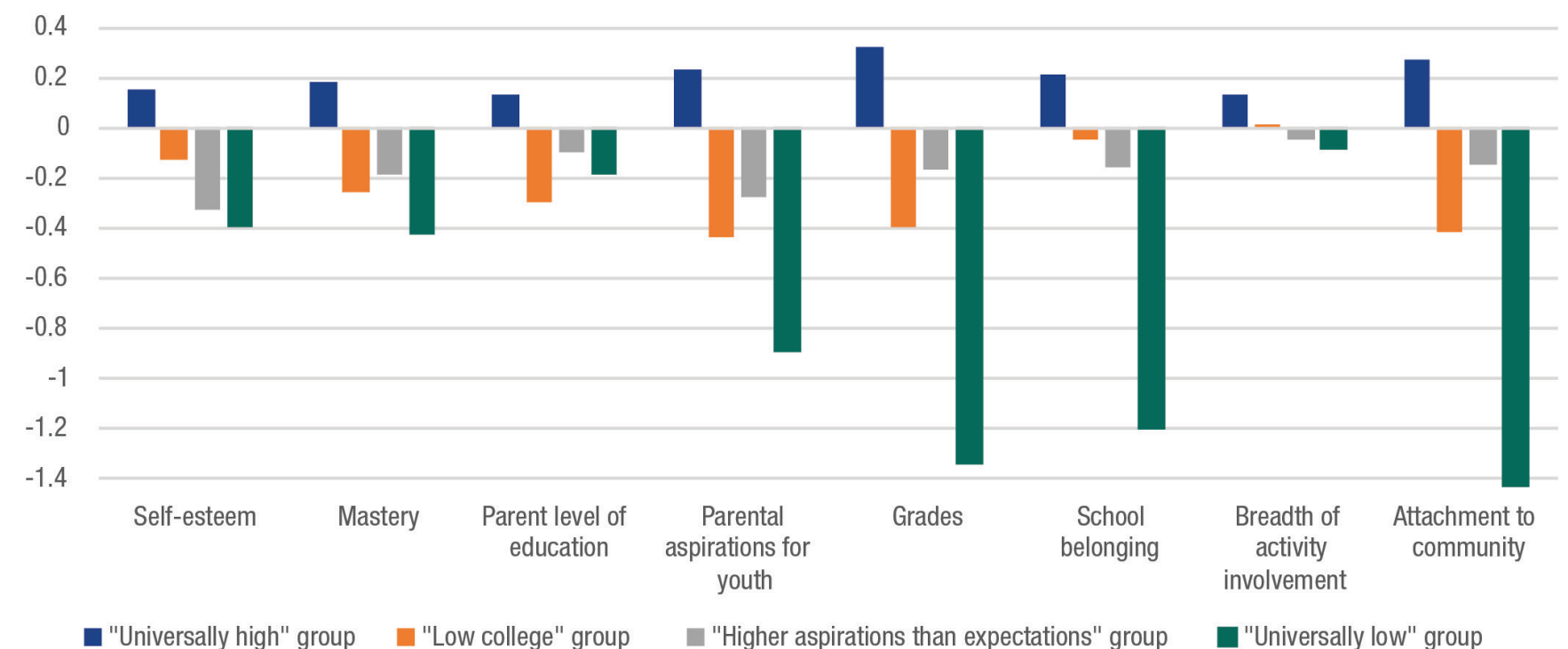

Note: Sample means for each variable set to zero are presented in Figure 4-6 to illustrate whether subgroup means were above or below the overall sample average. Source: Coös Youth Study Data.

All of these high school perceptions and experiences mattered for how Coös students felt in the $12^{\text {th }}$ grade about their futures, except activity involvement (see Figure 4-6). It should be noted, though, that activity involvement has been shown in previously published work from the Coös Youth Study to positively impact things like self-esteem, grades, and sense of school belonging. ${ }^{12}$

The four experiences earlier in high school that were most strongly related to Coös youths' future aspirations and expectations in $12^{\text {th }}$ grade were attachment to community, grades, school belonging, and perception of parental aspirations for their futures. For example, you can see how much lower Coös youth in the universally low subgroup viewed their attachment to the community earlier in high school compared to the other subgroups. The $12^{\text {th }}$-graders in the universally high future orientation subgroup reported having the most positive perceptions and experiences, earlier in high school, compared to their peers in each of the other future orientation subgroups. It is important to consider how enhancing youth experiences in these areas, as early as possible in their education, could elevate future aspirations, expectations, and attainment.

\section{Implications}

We found three areas of focus for enhancing youth development and community vitality.

- High school students who do not see their futures as important and who do not feel confident that they can reach their future goals face challenges transitioning to adult roles. High school grades, attachment to community, perception of school belonging, and perception of parents' aspirations were most strongly linked to future orientation later in high school. Efforts to support students' academic performance, connect students intentionally with people and organizations in their home communities, provide a school climate that is positive for the full range of students, and help parents engage with their children around future-oriented decisions and goals could help enhance youth development and increase young people's future orientation.
- Boys growing up in Coös face greater challenges envisioning a successful future and transitioning to adult roles than girls do. Previously published findings from the Coös Youth Study have highlighted areas of vulnerability for males in the county. For example, boys reported significantly lower levels of involvement in out-of-school activities, higher levels of substance use, and lower perceived opportunities in their community, and they were significantly less likely to report having a mentor compared to girls.

Boys in Coös need help seeing a clearer role for themselves in the existing economy. The largest industries in the county are health care, social assistance, retail trade, and services. Many of the jobs in these industries are perceived as stereotypically female; however, greater exposure through job shadowing, career fairs, and internships during high school may open up possibilities to male students. High schools could also work with businesses and industries to provide training opportunities in jobs like transportation and utilities. 
- Young people with the highest aspirations and expectations are the least likely to see themselves living in Coös in adulthood. This finding is similar to one reported in a recent paper that adolescents with the highest levels of community attachment were less likely to see themselves living in Coös in adulthood. ${ }^{13}$ Other rural communities have faced similar concerns. Rural leaders are asking themselves how they can retain more ambitious and confident young people, how they can attract young people back to the regions, and how they can better support the students who are less accomplished or driven and more likely to stay.
Communities in Coös are already engaged in efforts that may encourage the recruitment and retention of college-educated young professionals. For example, some are creating opportunities for business and social networking (like Rec After Hours), and others are addressing the technological infrastructure in the county. Perhaps Coös can do even more to capitalize on its location and its rich outdoor recreation opportunities. Additional opportunities may exist around initiatives that encourage high-performing high school students, through incentives, to pursue higher education in a field that has career links to areas of economic growth in Coös.

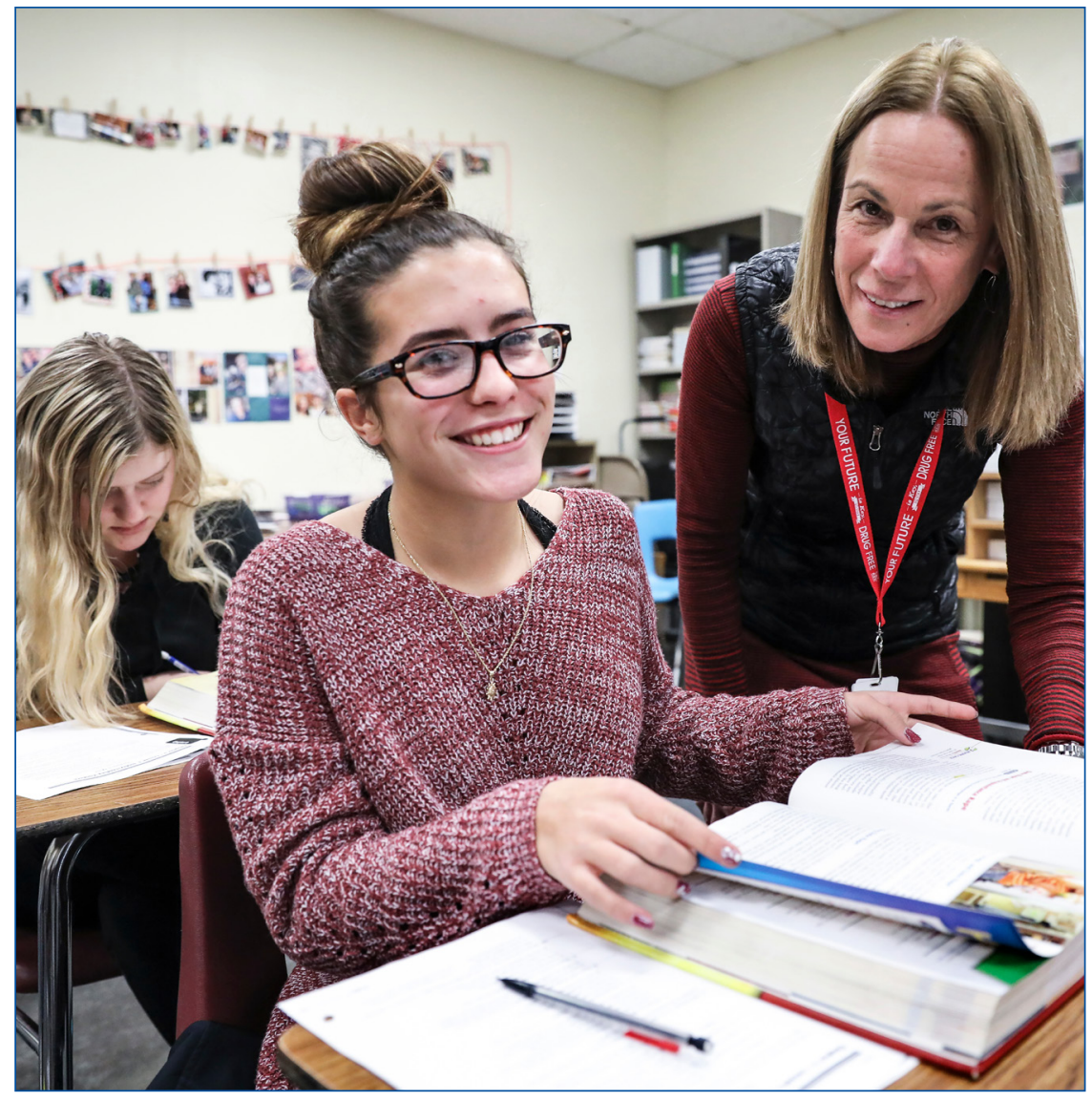

Nationally, secondary education has shifted even more toward college preparation. However, in order to ensure the workforce readiness and career success of youth who do not go to college, more efforts and training programs are needed to better prepare Coös youth for entry into the jobs currently available in Coös.

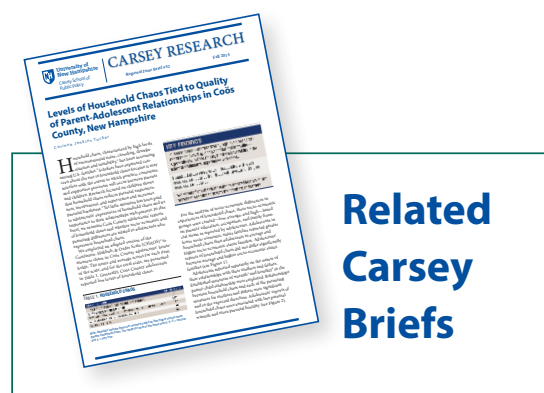

»Coös County Youth and Outof-School Activities - Patterns of Involvement and Barriers to Participation

॥Youths' Opinions About Their Opportunities for Success in Coös County Communities

॥ Too Much Free Time: Coös County Youth Who Are Least Involved in Out-of-School Activities Are Most Likely to Use Drugs \& Alcohol

» Out-of-School Time Matters: Activity Involvement and Positive Development among Coös County Youth

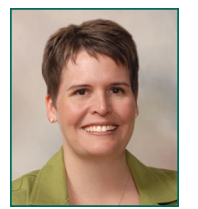

Erin Hiley Sharp, $\mathrm{PhD}$, is an associate professor of human development and family studies at the University of New Hampshire, and a faculty fellow at the Carsey School of Public Policy (Erin. Sharp@unh.edu). 


\title{
5. When We Foster a Sense of Community, Everybody Wins
}

\author{
Cesar J. Rebellon
}

$\Delta$ subjective sense of community can have important implications for developmental well-being and for long-term migration plans. ${ }^{1}$ Youth with a strong sense of community may, for example, feel socially accepted at school, be eager to participate in local events, believe that community members support one another, and perceive that adults care about what they think. ${ }^{2}$ In the short term, those youth who feel a stronger sense of community may be better equipped to succeed academically and may exhibit better emotional or behavioral health. In the long term, a stronger sense of community may increase youths' desire to build a long-term future in Coös, even if they leave for a time to seek educational and professional experiences elsewhere.

Figure 5-1 depicts four graphs demonstrating the ways in which a strong sense of community is associated with positive outcomes among the youth who participated in our study. First, it examines whether those who reported a high sense of school belonging in 2008 (orange bars) were more prone than those who reported a low sense of school belonging (gray bars) to report positive outcomes and/or to report greater long-term investment in making Coös County their permanent residence. Students with a high sense of school belonging were those who reported higher agreement with such statements as "I feel I belong at this school," and "other students accept me as I am." Among those youth who reported a low sense of belonging, only 44 percent earned mostly As and Bs in school in 2008; the share among those who reported a high sense of belonging was 55 percent. Among other outcomes, 44 percent of those with low belonging reported high levels of depression, compared to only 21 percent of those with

\section{KEY FINDINGS}

» Youth with a stronger sense of community do better academically, emotionally, and behaviorally.

» Youth who feel heard during childhood and adolescence may be more prone to desire a long-term future in Coös County even if they leave for a period of time during early adulthood to pursue educational or professional opportunities elsewhere.

» The sense of community among Coös youth is strong and remained resilient in the face of the Great Recession, with the exception of youth voice, which remains low in comparison to school belonging, community integration, and community support.

high belonging; 49 percent of those with low belonging reported involvement in delinquent behavior, compared to only 35 percent of those with high belonging; and 34 percent of those with low belonging remained actively involved in our study long enough to complete our final, post-high school survey (Wave 6), compared to 42 percent of those with high belonging. Among those respondents who remained in our study long enough to complete our Wave 6 survey, those who reported a high sense of school belonging in 2008 were slightly more likely to report living in Coös and slightly more likely to desire a longterm future in Coös than were their low-belonging counterparts. The latter two differences between high- versus low-belonging respondents, however, fell within the margin of error (i.e., these differences were statistically negligible).

Second, Figure 5-1 compares youth who reported low versus high community integration. Youth with a strong sense of community integration were those who agreed that they were part of their community, cared strongly about it, reported being proud of it, and reported being happy to participate in community events. Forty-five percent of those reporting low integration

\section{KEY IMPLICATIONS}

॥ To promote positive youth development, it is important that adults in Coös County continue to foster a sense of community among youth.

» While it will be healthy for some youth to leave Coös County for periods of time, enticing some to return later may involve more than jobs or economic development.

» Coös County might benefit in multiple ways by doing more to convince youth that their concerns and opinions matter to adults in the community.

earned mostly As and Bs in school in 2008 , compared to 52 percent of those reporting high integration. Among other outcomes, 42 percent of those with low integration reported high levels of depression, compared to only 23 percent of those with high integration, and 57 percent of those with low integration reported involvement in delinquent behavior, compared to only 32 percent of those with high integration. By the conclusion of our study 

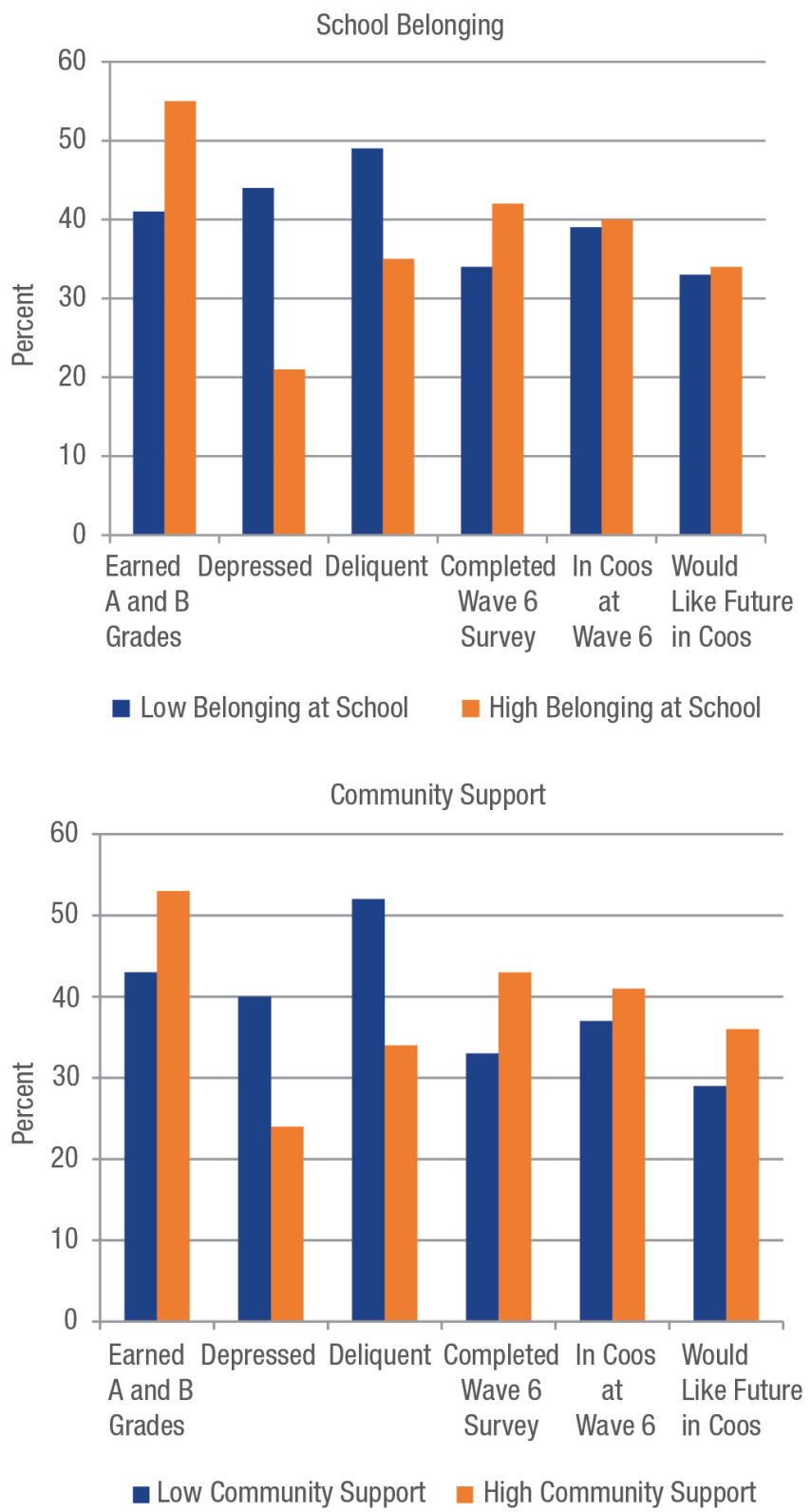
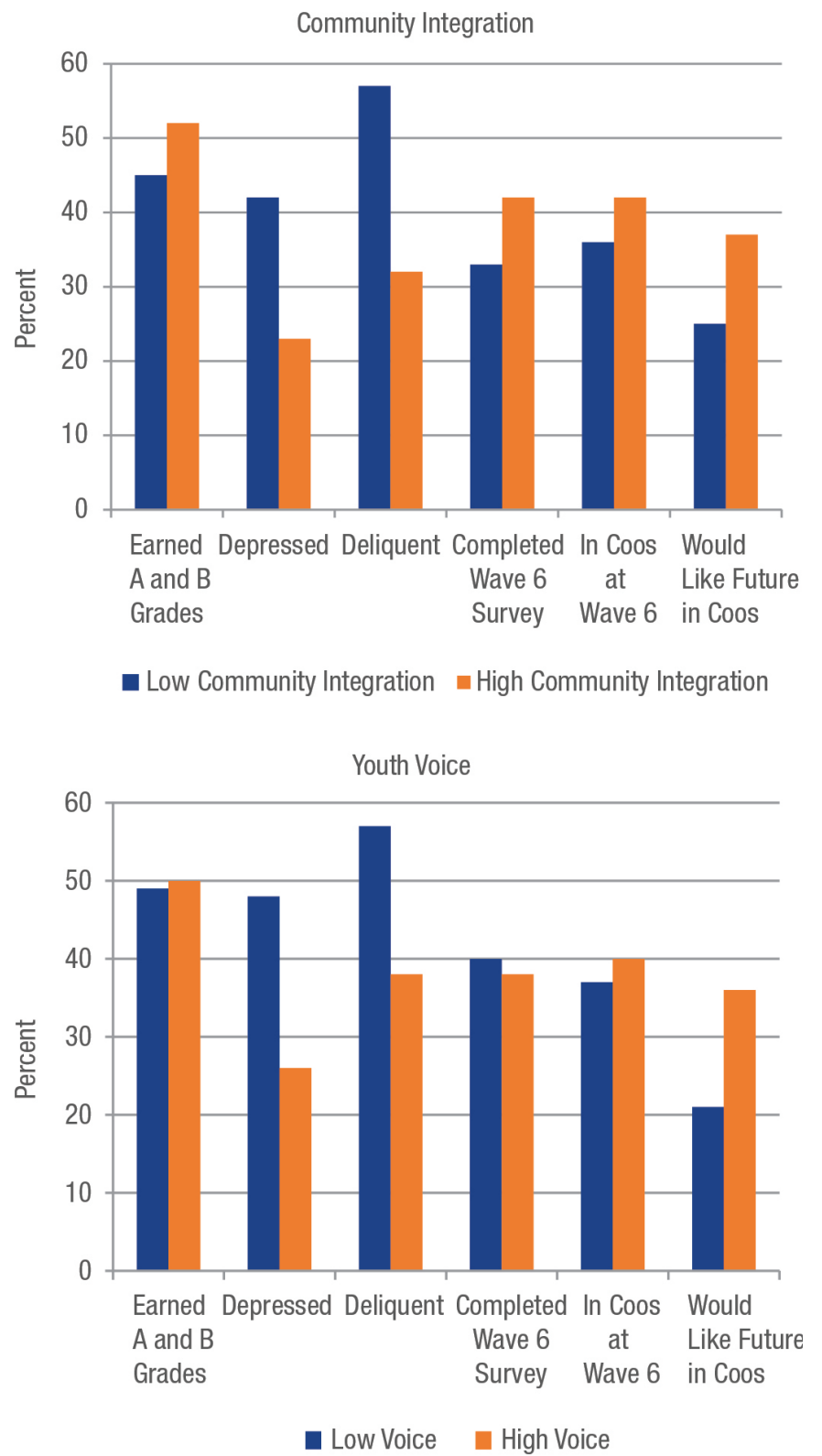

\section{Source: Coös Youth Study Data}

(i.e., our Wave 6 survey), those who reported low community integration in 2008 were less likely to have remained in our study than those who reported high community integration (33 versus 42 percent). Low integration respondents were less likely to remain in Coös by Wave 6 than were high integration respondents, but this difference was very small. A slightly larger difference emerged, however, between low- and high-integration respondents' desires to pursue a long-term future in Coös (25 versus 37 percent, respectively).
Third, Figure 5-1 compares youth who perceived a low versus a high sense of community support in 2008 . Youth with a high sense of community support were those who believed that people their community were willing to help their neighbors and that people in their community could be trusted. Forty-three percent of those reporting low support earned mostly As and Bs in 2008, compared to 54 percent of those reporting high support. Among other outcomes, 40 percent of those perceiving low support reported high levels of depression, compared to only 24 percent of those perceiving high support, and 52 percent of those perceiving low integration reported involvement in delinquent behavior, compared to only 35 percent of those perceiving high support. By the conclusion of our study (i.e., our Wave 6 survey), those who perceived low support in 2008 were less likely to have remained in our study than those who perceived high support (33 versus 43 percent).

While school belonging, community integration, and community support 
were generally associated with the same outcomes, a different story emerges when we turn to youth voice. Youth with high perceptions of voice in their community were those who believed that adults in their community cared about what kids think. Figure 5-1 shows that youth reporting low voice were much more likely to report depressive symptoms and delinquency than were youth reporting high voice. These outcomes mirror our findings for school belonging, community integration, and community support. In contrast to those prior findings, however, Figure 5-1 reveals that youth voice is strongly associated with youth intentions to build a long-term life in Coös County. Among those who perceived a high degree of youth voice in their communities in 2008, 36 percent reported at Wave 6 that they hoped to make Coös County their long-term home. Among those who perceived a low degree of voice in their communities in 2008, only 21 percent hoped to make Coös County their long-term home.

Supplemental analysis suggests several further insights concerning the association between youth voice and a long-term preference for building a life inside, rather than outside of, Coös County. First, the association between youth voice and long-term plans to live in Coös emerged regardless of whether respondents were living inside or outside of Coös at Wave 6. Second, regardless of where they were living at the time of the Wave 6 survey, respondents who perceived job availability to be improving in Coös were more likely to report that they would ideally like to make Coös their long-term home. Third, even after adjusting statistically for Wave 6 perceptions of job availability in Coös and for whether the respondent was living in Coös at Wave 6, Wave 1 perceptions of youth voice were sig- nificantly associated with a long-term desire to live in Coös at Wave 6.

Given that a sense of community is associated with a number of important outcomes, we also examined whether school belonging, community integration, community support, and youth voice changed among Coös youth over time prior to participants' high school graduation (Figure 5-2). Such changes may occur in two fundamental ways. First, perceptions of Coös County within a given age cohort may change as a normal part of the aging process. Second, perceptions of Coös County at a given age may change across successive generations in response to the region's changing social and economic circumstances. Given that the Coös Youth Study provides data across multiple time points from two different age cohorts, we can assess both types of change.

Figure 5-2 suggests that Coös youth generally have positive perceptions of

Figure 5-2. Did Youths' Sense of Community Change in Coös County Between 2008 and 2013 ?

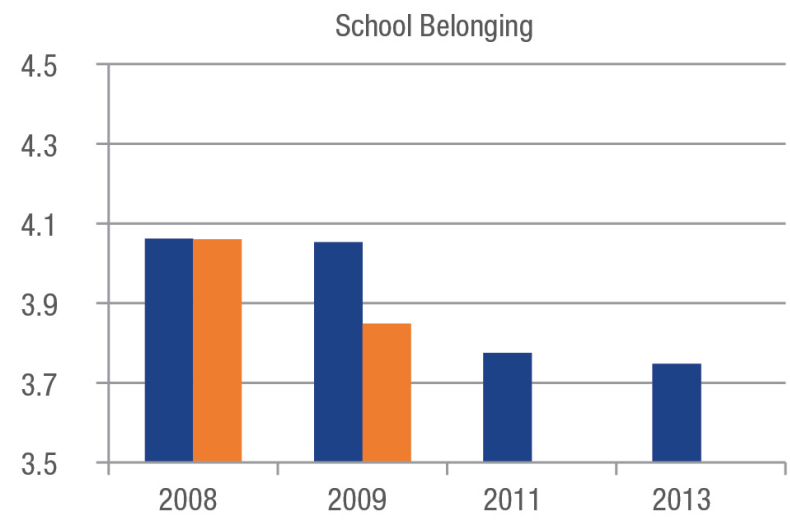

Community Support

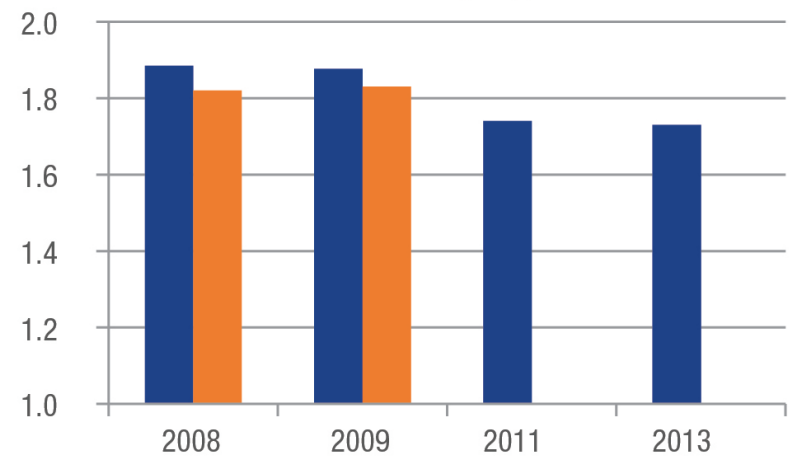

Community Integration

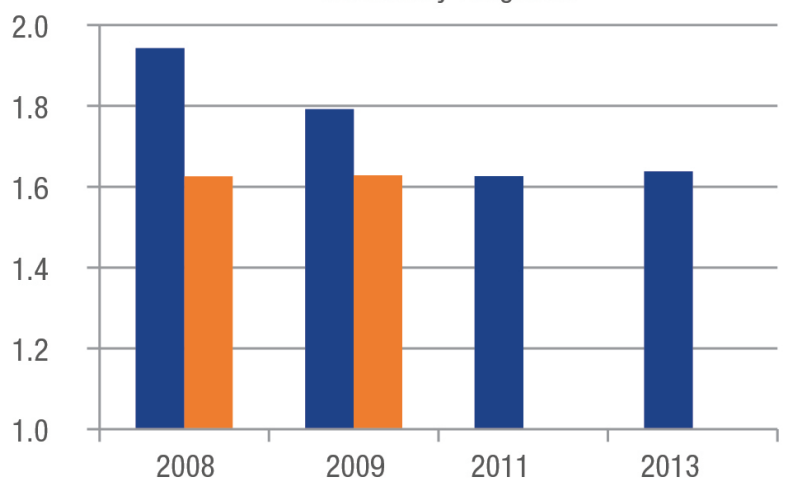

Youth Voice

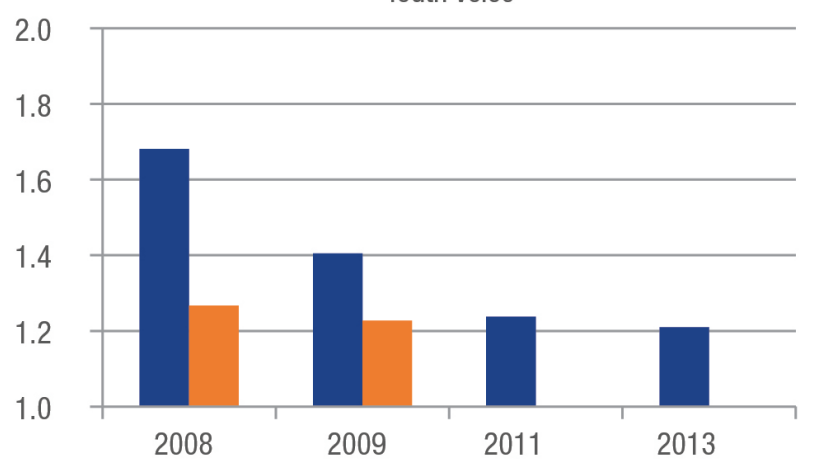


school belonging, community integration, and community support. For school belonging, the lowest possible score was 0 and the highest possible score was 6 , and so the consistent values above 3 mean that youth in Coös consistently tended to feel a positive sense of belonging in their schools. Similarly, for perceived community integration and community support, the lowest possible scores were 0 and the highest possible scores were 3 , and so the consistent values above 1.5 mean that youth in Coös consistently tended to feel that they were part of their community and that their community could be counted on as a source of social support.

At the same time, however, members of both age cohorts generally had negative perceptions of the degree to which adults in their communities cared about what kids thought. For the older cohort, the average rating of perceived youth voice was less than 1.5 both in 2008 , when they were in $11^{\text {th }}$ grade, and in 2009 , when they were in $12^{\text {th }}$ grade. For the younger cohort, while the average rating of perceived youth voice was above 1.5 in 2008, when they were in $7^{\text {th }}$ grade, it was less than 1.5 in each of the three subsequent years listed in Figure 5-2. These results mean that, with the exception of the younger cohort in 2008, youth in Coös tended to believe that adults did not value the opinions of youth in the region.

With respect to changes over time between 2008 and 2013, average perceptions of school belonging, community integration, community support, and youth voice declined substantially between 2008 and 2013. Nonetheless, overall results from Figure 5-2 reveal an optimistic story in the context of the economic challenges facing Coös County following the Great Recession. Specifically, even at their lowest values in 2013, average perceptions of school belonging remained above their neutral midpoint of 3 , while average perceptions of community integration and community support remained above their neutral midpoint of 1.5. This means that, on balance, Coös youth retained positive beliefs about their communities between 2008 and 2013. Of particular note, by the time members of the younger cohort reached 12th grade, their average ratings of all four measures in Figure 5-2 were virtually identical to the average ratings that members of the older cohort reported four years earlier, when they were in 12th grade. The declines apparent in Figure 5-2 therefore appear to reflect a normal part of the aging process rather than generational changes stemming from an increase in the region's unemployment rate during the Great Recession. ${ }^{3}$ Had the latter been the case, we would have expected the younger cohort's 12th-grade averages in 2013 to dip significantly below the older cohort's 12th-grade averages in 2009.

Taken together, the above findings have important implications for both positive development among youth in Coös County and for the overall future of Coös County itself. With respect to youth development, our findings speak to the importance of community connection for healthy academic, mental, and behavioral development. In particular, they suggest that youth in Coös may be more likely to achieve stronger academic outcomes, maintain positive mental health, and abstain from delinquency when they develop a strong sense of community. Community leaders and adults more generally might therefore seek to develop community programming with an eye toward increasing youths' perceptions of school belonging, community integration, and community support.

With respect to the overall future of Coös County, our findings speak to a potentially counterintuitive conclusion about how to reverse, or at least slow down, recent trends in youth outmigration. Between 2000 and 2010, Census Bureau data indicate that the number of Coös County adults age 25-34 declined by more than 10 percent, and the number age 35-44 declined by more than
20 percent. Nearly three-quarters of Coös adults in 2010 reported that they viewed population decline as a pressing issue in the region. ${ }^{4}$ On the one hand, our findings support the intuitive notion that outmigration has occurred partly in response to limited job opportunities in the wake of the Great Recession and partly in response to the long-term economic changes that preceded the recession in Coös County. On the other hand, our findings simultaneously suggest that economic concerns may not be the only factors that influence whether those who leave Coös to pursue educational and economic opportunities might consider returning. Instead, our findings suggest that young adults who leave Coös are more likely to return if they felt heard within their communities of origin during their youth. In light of the relatively low levels of perceived voice among Coös youth between 2008 and 2013, community leaders in Coös County might therefore do well to develop community programming with an eye toward convincing them that adults in Coös care about their concerns and opinions.

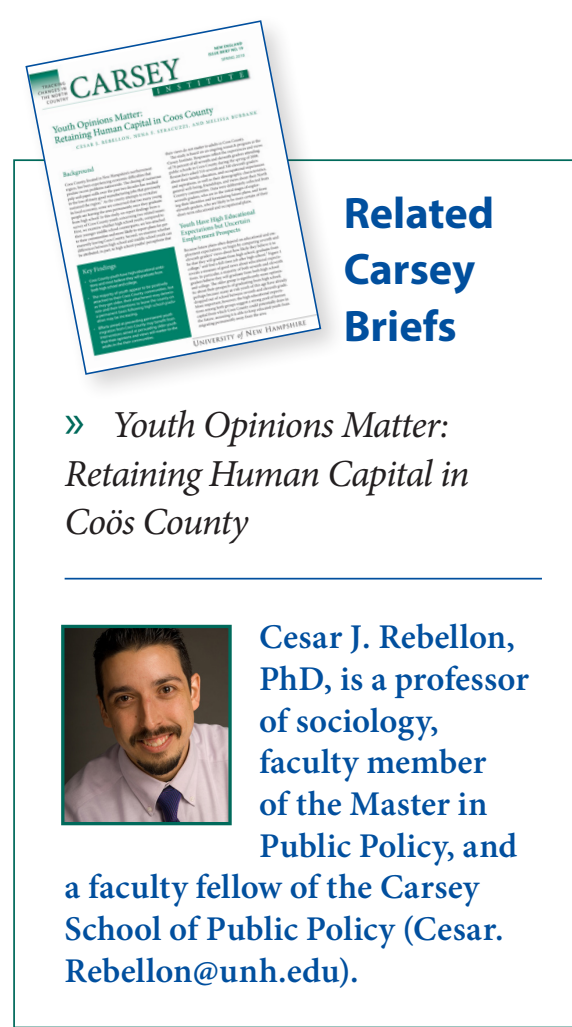




\section{Conclusion}

$\mathrm{E}$ ach section of this report discusses a distinctive area of research. The topics span the individual, home, school, and community contexts. While we hope this broad range offers something valuable to every reader, it also challenges us to draw overarching lessons learned. What are the common threads running through these findings, and the findings throughout the ten years of the study? To conclude, we present some higher-level themes emerging from this ambitious project.

- The home environment is where it all begins. A stable home environment is the foundation of healthy youth development. Although household chaos was not found to be a pervasive problem among Coös adolescents, for those who experience it, interventions that strengthen household organization and routines may have lasting benefits for health and well-being.

\section{- Aspirations and expectations} become reality. These findings may demonstrate that young people understand which opportunities are open to them and which feel legitimately out of reach. However, visions of the future may be restricted when awareness of viable educational and career pathways is incomplete. Conditions change. Employment patterns shift. Our previous research has found youth to be keenly aware of the impact of the area's manufacturing decline and the Great Recession as they witnessed their parents and other community members losing the mill jobs that had secured a decent income for the generations before. Those without a clear pathway to success in the changing economy-especially young men without the means to leave the areamay need more information and more support to craft a plan for productive participation in the workforce after high school. Of course, economies are dynamic, and what makes sense today may not make sense tomorrow. Ongoing communication and collaboration among schools, community colleges, four-year colleges, industries, and nonprofits may help to foster smoother transitions to higher education and the workforce for all students.

\section{- Community attachment and} youth voice matter a lot. Community attachment has been linked to an array of positive outcomes throughout the study. As reported here, it reduces the risk that stressful life events in youth will lead to depression and substance misuse in young adulthood. Youth voice-the perception among youth that they are being heard by the adults in the community-emerged as an important factor in youth retention, even after accounting for changes in local job prospects. Young people, especially those with the highest aspirations and expectations for the future, may leave the area to pursue educational and employment opportunities, but we have learned here about what might draw them back as their plans evolve. The teens and twenties are a time of exploration during which many of us spend time away from the security of our hometowns to see the wider world. Other factors may come into play in the late twenties, thirties, and beyond, such as having parents or other relatives nearby if we are considering starting our own families. The timing of our study is such that we can measure only current intentions, which may prove a flawed predictor of future behaviors. Nevertheless, this report offers important insights into why some may desire to return at some point, and how that desire can be developed and fostered starting at perhaps a younger age than expected.

None of this is to suggest that the local economy is not a driving force in outmigration decisions or that it should not be a priority. Regional economic change may be possible, if very challenging, to achieve through formal intervention. However, such change happens in a long, slow arc, like turning around the proverbial ship. In this report are powerful findings that point to clear steps to take right now. For example, the Neil and Louise Tillotson Fund of the New Hampshire Charitable Foundation, the primary sponsor of this study, launched the Empower Coös Youth campaign in response to these findings. The fund's most recent initiative is a foundation grantmaking program driven by priorities identified by young people serving on a youth grantmaking committee. We strongly encourage readers to connect with youth in their own communities to listen to their concerns and ideas as well. If no platform for this kind of discussion exists in your community yet, then perhaps it is time to create one.

Although this report represents the culmination of our ten-year research project, we hope that the data and findings from the Coös Youth Study inform rural research and initiatives that support rural communities, regionally and nationwide, for years to come. We have strived to make the information coming out of the study accessible and applicable to a wide audience through our Carsey research briefs as well as numerous presentations and conversations with regional stakeholders. What will you, the reader, do next? What information do you need to take your next steps? Please contact us at coos.youth. study@unh.edu to let us know. 


\title{
Appendix: About the Coös Youth Study
}

\author{
Eleanor M. Jaffee
}

$\mathrm{T}$ he Coös Youth Study followed two age groups or cohorts of youth into young adulthood by administering surveys at multiple points within a ten-year period. ${ }^{1}$ The first survey was conducted in 2008. All $7^{\text {th }}$ - and $11^{\text {th }}$-grade students at public schools in Coös County, New Hampshire (the graduating classes of 2013 and 2009, respectively) were invited to participate. The survey questionnaire was administered by paper and pencil onsite at each school by project faculty and staff. It encompassed a range of subjects, including participants' academic and career aspirations, perspectives on local economic opportunities, attachment to school and community, family relationships, and health and social behaviors (see Box A-1, Survey Items and Measures). Participants were offered $\$ 10$ gift cards for regional retailers in appreciation of their time. Six hundred fifty-seven students participated in the 2008 survey, representing 83 percent of all enrolled students in their respective grades that year. $^{2}$

The next survey was administered in 2009 to the same students, then in $8^{\text {th }}$ and $12^{\text {th }}$ grades, as well as to students who had not participated before but who were enrolled in the target grades that year. Six hundred seventyeight students, or 88 percent of those enrolled, participated. The younger cohort was still in high school for our third and fourth surveys. In 2011, as $10^{\text {th }}$-graders, 95 percent of enrolled students participated, and in 2013, as $12^{\text {th }}$-graders, 96 percent participated.

Not surprisingly, however, once the older cohort participants graduated from high school, retaining them as participants became a challenge. Because we were no longer able to administer paper and pencil surveys to the older cohort as a group in school, and because many had left the area to attend college or pursue job opportunities, we administered the survey primarily online using contact information provided while participants were in high school and updated at each survey wave. A mail survey was also made available upon request by the participant in response to communications we sent by email, phone, or letter. The value of the gift cards increased to $\$ 20$, the retailers changed to Amazon and Walmart, and we also offered entry into raffles for prizes including iPods and Beats headphones. We made great efforts to contact the participants, using letters, phone calls, social media posts and messages, advertisements in local newspapers, and presence at community venues. ${ }^{3}$ Nevertheless, older cohort response rates declined to a little under 60 percent in 2011 and 2013, and to about 40 percent in 2015 and $2017 .{ }^{4}$

Retention proved an even greater challenge with younger cohort participants after they graduated. Perhaps because they had experienced a higher level of online survey or social media outreach fatigue by the time they completed high school, as these approaches became more mainstream, fewer younger cohort participants continued their participation in the study compared with the older cohort. Compounding this challenge, the graduating class of 2013 was much smaller than the class of 2009 due to declining enrollment resulting from population loss. During the study period, county-wide public school enrollment in the graduating class of 2013 dropped from 382 to 294 , a decrease of 23 percent. ${ }^{5}$ Therefore, many younger cohort participants were already lost from the study prior to graduation. Younger cohort response rates were approximately 30 percent in 2015 and 2017. ${ }^{6}$ Our final response rate for the younger and older cohorts combined, four and eight years out of high school, respectively, was 34 percent.

\section{About Coös Youth Study Participants}

A total of 831 individuals participated in the Coös Youth Study surveys, with 434 in the younger cohort, and 397 in the older cohort. Of the six surveys administered over the ten years of the study, participants completed three or four of them on average, although not necessarily in a row; some skipped a survey but later returned to complete another one. Twenty-three percent of the younger cohort and 15 percent of the older cohort completed all six surveys. The average number of surveys completed was significantly higher for female than for male participants. Twenty-eight percent of female participants compared with 10 percent of male participants completed all six surveys, and 65 percent of female participants completed at least one survey after high school compared with 44 percent of male participants, also a significant difference. Participants in the first survey (2008) were almost evenly split at 49 percent male and 51 percent female compared to approximately 53 percent male and 47 percent female among enrolled students through the period of school data collection (2008-2013). By the sixth survey (2017), participants were 37 percent male and 63 percent female (Figure A-1). In other words, young women participants were more likely to join the study, and much more likely to stay in the study long term, than young men were.

Not surprisingly, given the racial composition of Coös County and New Hampshire as a whole, most of the study participants were white: 93 percent at the start of the study in 2008 and 97 percent by the end of the study in 2018. Two percent of participants or fewer reported their main racial or ethnic background as Native American, Asian American, African American, Hispanic or Latino/a, or "other." 
In addition to the influence of age cohort and sex, the youth who continued to participate in our study tended to have the future expectation of college graduation. Participants who responded that they were likely to graduate from college were 1.2 times as likely to participate in the survey after high school. Taken together, sex, age cohort, and college expectation accounted for about 23 percent of the likelihood of survey participation after high school graduation. We have no household income data from the early years of the study, as we considered our participants too young to report this information accurately. However, students' reports of their father's level of education, which is sometimes used as a substitute measure of household income, did not seem to play a role in the likelihood of survey participation. Neither did participants' future expectations to stay in or leave the region.

\section{Where Are They Now?}

The sixth and final Coös Youth Study survey was conducted from October 2017 through March 2018. Participants in the two age cohorts were on average 22 and 26 years old. Overall, approximately 42 percent reported that they still lived in Coös County the majority of the time. Among older cohort participants, the percentage remaining in Coös declined in each survey since we started asking the question in 2011, the first survey after participants graduated high school. That year 49 percent reported living in Coös County the majority of the time; by 2017, the share had fallen to 39 percent.

Twenty-two percent of all participants reported living in New Hampshire but outside of Coös County, 35 percent reported living outside New Hampshire, and less than 2 percent reported living outside of the United States. Of those living in New Hampshire but outside Coös County, about one-fifth were in neighboring Grafton

Figure A-1. Survey Participation by Sex Within Age Cohort, 2008-2017

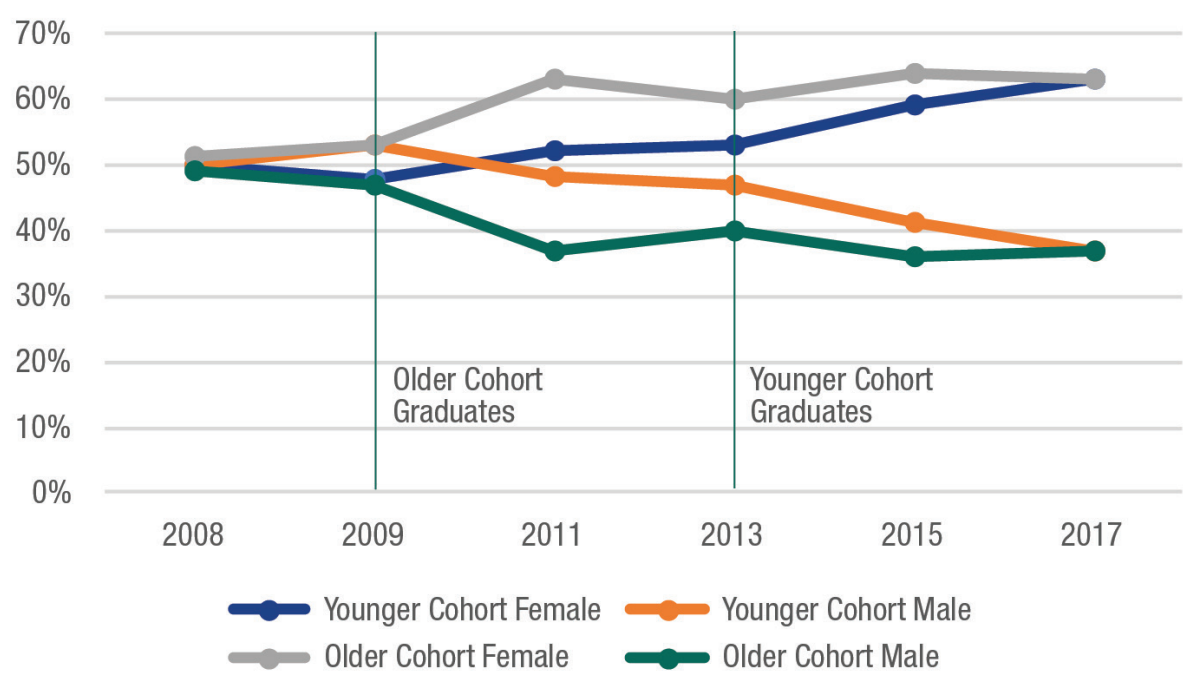

Source: Coös Youth Study Data

Figure A-2. Comparison of Current and Ideal Future Residence, 2017-18 ( $\mathrm{n}=298)$

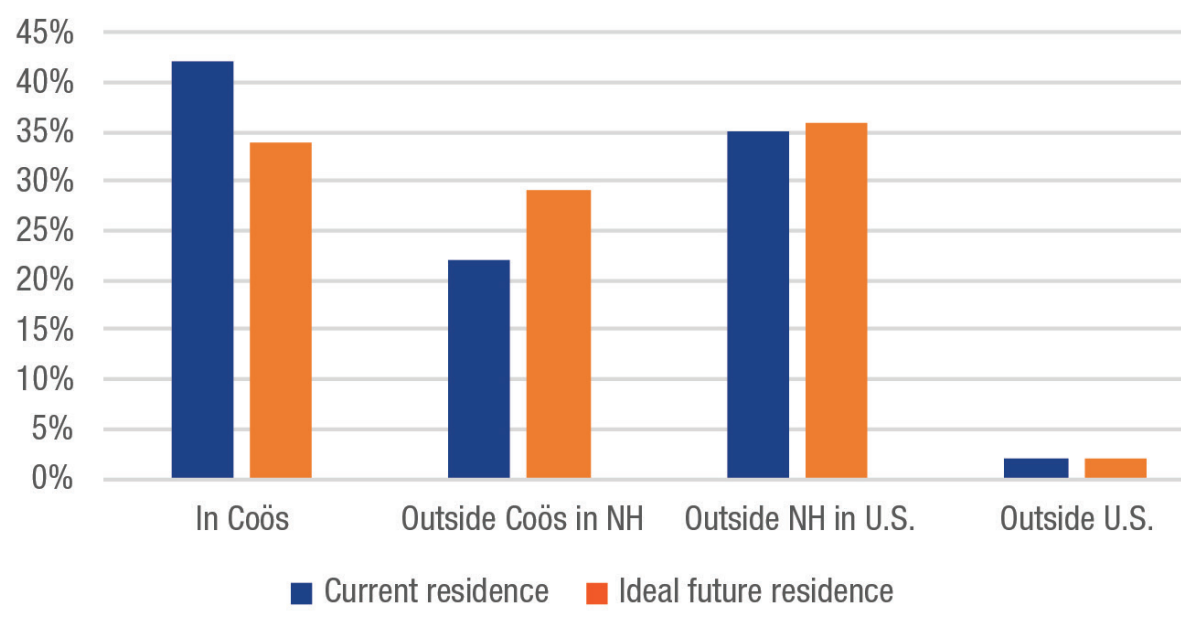

Source: Coös Youth Study Data

County and the remainder mostly in Hillsborough, Merrimack, Belknap, and Rockingham Counties. Of those living outside New Hampshire but in the United States, one-third were in the South, a little over one-quarter in the Northeast, and the remainder in the Midwest and West. Forty-four percent described the place where they lived the majority of the time as a small town, 27 percent as a city, 15 percent as a rural area, 9 percent as the suburbs, and 4 percent as a major metropolitan area.

When asked where they would ideally like to make their permanent residence in the future (Figure A-2), just over a third (36 percent) said outside of New Hampshire, another third (34 percent) said Coös County, and just less than a third (29 percent) indicated New Hampshire but outside of Coös County. Less than 2 percent said they would like to live outside the United States. Most participants were already where they wanted to be: approximately two-thirds in each of these categories said they would like to permanently reside where they currently lived. However, most of the remaining third of those living outside Coös County did not report Coös County as their ideal future residence. Coös County may thus perhaps expect 
further outmigration to occur, whereas migration out of New Hampshire and the United States may have stabilized-at least among our participants at this point in time.
Whether participants currently reside inside or outside of Coös County, large majorities reported that they cared about issues and events in the county ( 89 percent and 78 percent, respectively). Fewer, but still at least half in both groups, also felt connected to issues and events in the county (62 percent and 50 percent, respectively).

\section{Box A-1. Survey Items and Measures (2008-2018)}

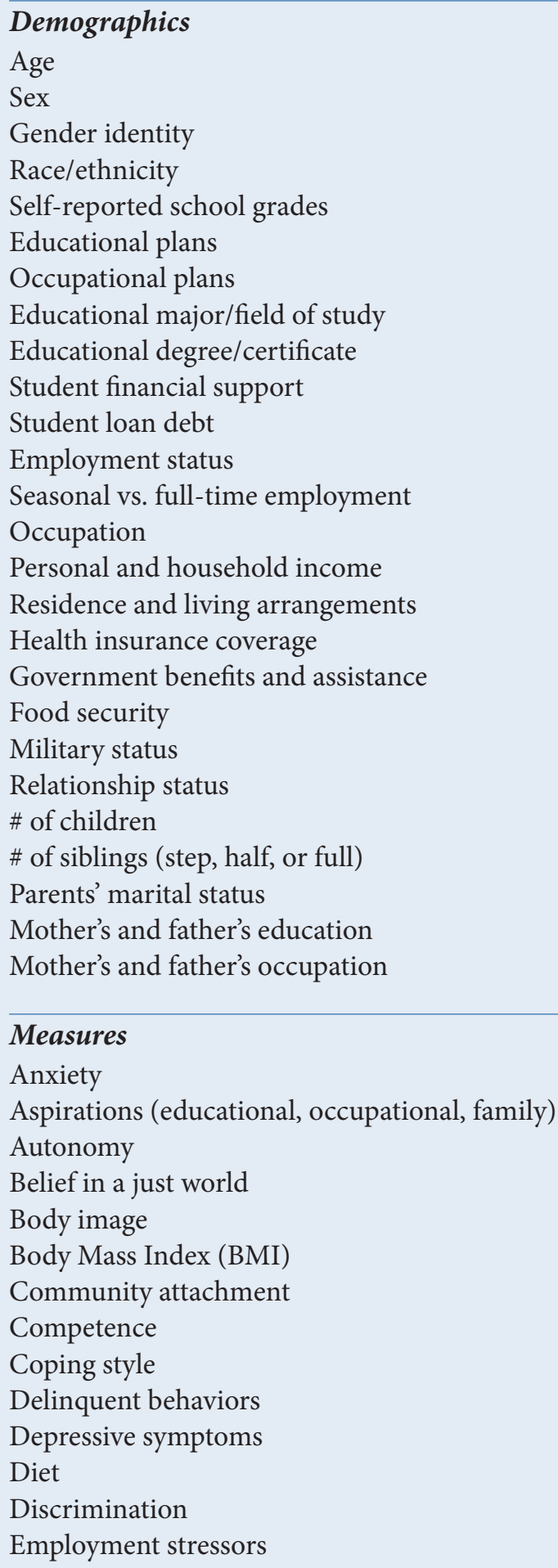

\section{Measures}

Anxiety

Aspirations (educational, occupational, family)

Autonomy

Belief in a just world

Body image

Body Mass Index (BMI)

Community attachment

Competence

Coping style

Delinquent behaviors

Depressive symptoms

Diet

Discrimination

Employment stressors

Measures (cont.)

Expectations (educational, occupational, family) Extra-curricular activities

Financial independence

Financial strain

Guilt

Household chaos

Intimate relationship stressors

Job satisfaction

"John Henryism" (individualism v. collectivism)

Mastery

Mental health

Mental health treatment

Mentor relationship

Parental attachment

Parental conflict

Parental expectations

Parental problem substance use

Parental stressors

Peer delinquency

Peer expectations

Physical health

Quality of life

Religiosity

School connectedness

School stressors

Self-control

Self-esteem

Self-sufficiency

Sibling attachment

Sibling relationship quality

Stressful life events

Substance use

Teacher attachment

Transition to adulthood

\section{Youth Perspectives}

Beliefs regarding climate change

College and work readiness

High school education satisfaction

Perceptions of opportunities in Coös

Perceptions of federal prison impact 


\section{Endnotes}

\section{Executive Summary}

1. Source of 2000 data: U.S. Census Bureau, "Households and Families: 2000” (Table QT-P10), Census 2000 Summary File 1, Matrices P17, P26, P27, P33, P34, and P35. Source of 2017 data: U.S. Census Bureau, "Households and Families" (Table S1101), American Community Survey Five-Year Estimates, 2013-2017.

\section{Introduction}

1. U.S. Census Bureau, "Annual Estimates of the Resident Population for Selected Age Groups by Sex for the United States, States, Counties, and Puerto Rico Commonwealth and Municipios," (Table PEPAGESEX), June 2018.

2. U.S. Census Bureau, "Median Income in the Past 12 Months (in 2016 Inflation-Adjusted Dollars)" (Table S1903), 2012-2016 American Community Survey Five-Year Estimates.

3. Weather Channel, Berlin, NH (03570) Monthly Weather, 2018, https://weather.com/weather/monthly/l/Berlin+NH+03570:4:US.

4. See M. Dillon, "Forging the Future: Community Leadership and Economic Change in Coös County, New Hampshire" (Durham NH: Carsey Institute, 2012). See also C.M. Duncan, Worlds Apart: Why Poverty Persists in Rural America, 2nd ed. (New Haven, CT: Yale University Press, 2014).

5. After the Fraser Papers closure, this mill reopened in 2012 under new ownership again as Gorham Paper and Tissue. Since then it has been operating intermittently with varying numbers of employees and has struggled to pay off back taxes and loans from the city (see, e.g., http://indepthnh.org/2017/01/15/gorham-paper-tissue-is-making-progress-paying-off-debt/).

6. New Hampshire Economic Security, “Coös County Perspectives: The Groveton Mill Closures,” 2007, https://www.nhes.nh.gov/ elmi/products/documents/cooscounty-groveton.pdf.

7. Bureau of Labor Statistics, “Local Area Unemployment Statistics, Labor Force Data by County”, http://stats.bls.gov/lau/home. htm, Series ID LAUCN330070000000003.

8. See, for example, the following press releases and news articles: https://www.shaheen.senate.gov/news/press/shaheen-berlin-prison-opening-a-boost-for-north-country-economy, http://www.sunjournal.com/berlin-nh-eyes-prison-jobs-loggingrevive-economy/, http://www.unionleader.com/article/20121022/NEWS07/710229969\&template=mobileart, http://www.nhpr. org/post/sound-money-can-atvs-reinvigorate-nhs-north-country-economy\#stream/0, https://www.boston.com/news/localnews/2017/11/04/atv-tourists-in-northern-new-hampshire-clash-with-locals.

9. Bureau of Economic Analysis, "Regional GDP \& Personal Income Table CA25N: Total Full-Time and Part-Time Employment by NAICS Industry," https://www.bea.gov/.

10. Sources of 2000 data: (1) U.S. Census Bureau, “Age Groups and Sex: 2000” (Table QT-P1), Census 2000 Summary File 1, Matrices P13 and PCT12; (2) U.S. Census Bureau, "Households and Families: 2000" (Table QT-P10), Census 2000 Summary File 1, Matrices P17, P26, P27, P33, P34, and P35. Sources of 2017 data: (1) U.S. Census Bureau, "Annual Estimates of the Resident Population for Selected Age Groups by Sex for the United States, States, Counties, and Puerto Rico Commonwealth and Municipios" (Table PEPAGESEX), April 1, 2010 to July 1, 2017, June 2018; (2) U.S. Census Bureau, "Households and Families" (Table S1101), American Community Survey Five-Year Estimates, 2013-2017.

11. Source of 2000 data: U.S. Census Bureau, "Poverty Status in 1999 of Individuals: 2000" (Table QT-P34). Census 2000 Summary File 3-Sample Data, Matrices PCT49, PCT50, PCT51, PCT52, PCT53, PCT54, and PCT55. Source of 2017 data: U.S. Census Bureau, "Poverty Status in the Past 12 Months of Families" (Table 1702), 2013-2017 American Community Survey Five-Year Estimates.

12. The focus of this section is on the six surveys conducted over ten years, which served as the primary source of data for this report. Interviews were also conducted with a subsample of study participants at three points in time.

13. New Hampshire Department of Education, "NH School and District Profiles," https://my.doe.nh.gov/profiles/.

14. Center for Rural Pennsylvania, “The Rural Youth Education Project: Third Wave” (Harrisburg, PA, 2010), http://www.rural. palegislature.us/ed_attainment_wave3.pdf. 


\section{Household Chaos and Adolescents' Future Plans, Parent-Child Relationships, and Well-Being}

1. A.P. Matheny, T.D. Wachs, J.L. Ludwig, and K. Phillips, "Bringing Order Out of Chaos: Psychometric Characteristics of the Confusion, Hubbub, and Order Scale," Journal of Applied Developmental Psychology 16, no. 3 (1995): 429-44.

2. C.R. Colocousis, “The State of Coös County: Local Perspectives on Community and Change” (Durham, NH: Carsey School of Public Policy, 2008), http://scholars.unh.edu/carsey/39.

3. S.R. Jaffee, K.B. Hanscombe, C.M.A. Haworth, O.S.P. Davis, and R. Plomin, “Chaotic Homes and Children's Disruptive Behavior: A Longitudinal Cross-Lagged Twin Study," Psychological Science 23, no. 6 (2012): 643-50; K. Deater-Deckard, Z. Wang, N. Chen, and M.A. Bell, "Maternal Executive Function, Harsh Parenting, and Child Conduct Problems," Journal of Child Psychology and Psychiatry 53, no. 10 (2012): 1084-91.

4. C.J. Tucker, E.H. Sharp, K. Van Gundy, and C. Rebellon, "Household Chaos, Hostile Parenting, and Adolescents' Well-Being Two Years Later," Journal of Child \& Family Studies 27 (2018): 3701-08.

5. C.J. Tucker, E.H. Sharp, K. Van Gundy, and C. Rebellon, “Household Chaos, Relationships With Parents, and Adolescents' Future Beliefs," Journal of Family Studies 23 (2017): 229-42.

6. K. Deater-Deckard, P.Y. Mullineaux, C. Beekman, S.A. Petrill, and C. Schatschneider, "Conduct Problems, IQ, and Household Chaos: A Longitudinal Multi-Informant Study," Journal of Child Psychology and Psychiatry 50, no. 10 (2009), $1301-08$.

7. J. Coldwell, A. Pike, and J. Dunn, "Household Chaos: Links With Parenting and Child Behavior," Journal of Child Psychology and Psychiatry 47, no. 11 (2006): 1116-22.

8. Tucker, Sharp, Van Gundy, and Rebellon, 2017.

9. T.D. Wachs and G.W. Evans, "Chaos in Context," in G.W. Evans and T.D. Wachs, eds., Chaos and Its Influence on Children's Development: An Ecological Perspective (Washington, DC: American Psychological Association, 2010): 3-13.

10. Tucker, Sharp, Van Gundy, and Rebellon, 2017.

11. Deater-Deckard, Wang, Chen, and Bell, 2012.

12. Tucker, Sharp, Van Gundy, and Rebellon, 2018.

\section{Mental Health, Social Stress, and Sense of Community}

1. Substance Abuse and Mental Health Services Administration, "Key Substance Use and Mental Health Indicators in the United States: Results From the 2016 National Survey on Drug Use and Health" (HHS Publication No. SMA 17-5044, NSDUH Series H-52) (Rockville, MD: Center for Behavioral Health Statistics and Quality, Substance Abuse and Mental Health Services Administration, 2017), https://www. samhsa.gov/data/.

2. Substance Abuse and Mental Health Services Administration, “2015-2016 National Survey on Drug Use and Health National Maps of Prevalence Estimates, By State” (Rockville, MD: Substance Abuse and Mental Health Services Administration, 2018), https://www.samhsa.gov/data/report/2015-2016-nsduh-national-maps-prevalence-estimates-state.

3. Karen T. Van Gundy, "Mental Health Among Northern New Hampshire Young Adults: Depression and Substance Problems Higher Than Nationwide" (Durham, NH: Carsey School of Public Policy, 2013), http://scholars.unh.edu/carsey/204.

4. Karen T. Van Gundy, Nena F. Stracuzzi, Cesar J. Rebellon, Corinna J. Tucker, and Ellen S. Cohn, "Perceived Community Cohesion and the Stress Process in Youth." Rural Sociology 76 (2011): 293-318.

5. Karen T. Van Gundy and Meghan L. Mills, “Teen Stress and Substance Use Problems in Coös: Survey Shows Strong Community Attachment Can Offset Risk" (Durham, NH: Carsey School of Public Policy, 2011) http://scholars.unh.edu/carsey/153.

6. Karen T. Van Gundy, 2013.

7. Karen T. Van Gundy, “Mental Health and Substance Misuse in the 'Drug-Infested Den,”' Saul O. Sidore Lecture Series, Center for the Humanities at the University of New Hampshire, September 13, 2018, Durham, https://youtu.be/DqKFfuZzwJY.

8. Karen T. Van Gundy et al., 2011. 
9. Karen T. Van Gundy, 2013.

10. Karen T. Van Gundy, "Substance Abuse in Rural and Small Town America” (Durham, NH: Carsey School of Public Policy, 2006), http://scholars.unh.edu/carsey/7.

11. Karen T. Van Gundy et al., 2011.

12. Charlotte Fabiansson, "Being Young in Rural Settings: Young People's Everyday Community Affiliations and Trepidations," Rural Society 16 (2006):47-61.

13. Karen T. Van Gundy and Meghan L. Mills, 2011.

14. Karen T. Van Gundy, 2013.

15. In the analyses presented in this section, we controlled statistically for early substance misuse as well as the respondents' age cohort (older or younger), parent status (if they had children or not), relationship status (if they were married/living as married or not), education level (whether or not they earned a degree after high school), and employment status (whether or not they worked full time).

\section{Coös Youths' Future Aspirations, Expectations, and Attainment}

1. National Center for Educational Statistics, "Rural Education in America”, 2017, https://nces.ed.gov/surveys/ruraled/.

2. U.S. Census Bureau, “QuickFacts: Coös County, New Hampshire”, https://www.census.gov/quickfacts/cooscountynewhampshire.

3. R. Seginer, "Future Orientation: Developmental and Ecological Perspectives," Springer Series of Human Exceptionality (New York, NY: Springer Science + Business Media, 2009).

4. P. Boxer, S.E. Goldstein, T. DeLorenzo, S. Savoy, and I. Mercado, "Educational Aspiration-Expectation Discrepancies: Relation to Socioeconomic and Academic Risk-Related Factors," Journal of Adolescence 34 (2011): 609-17.

5. Z.R. Mello, "Gender Variation in Developmental Trajectories of Educational and Occupational Expectations and Attainment From Adolescence to Adulthood," Developmental Psychology 44, no. 4 (2008): 1069-80.

6. C. Agger, J. Meece, and S-Y. Byun, “The Influence of Family and Place on Rural Adolescents' Educational Aspirations and PostSecondary Enrollment," Journal of Youth and Adolescence 47 (2018): 2554-68.

7. A.R. Tickamyer and D.A. Henderson, "Rural Women: New Roles for the New Century?” D.L. Brown and L.E. Swanson, eds., Challenges for Rural America in the Twenty-first Century (State College, PA: Penn State University Press, 2003).

8. L.J. Crockett, M.J. Shanahan, and J. Jackson-Newsom, "Rural Youth: Ecological and Life Course Perspectives,” R. Montemayor, G.R. Adams, and T.P Gullotta, eds., Adolescent Diversity in Ethnic, Economic, and Cultural Contexts: Advances in Adolescent Development, Vol. 10 (Thousand Oaks, CA: Sage Publications, 2002).

9. S.J. Beal and L.J. Crockett, "Adolescents' Occupational and Educational Aspirations and Expectations: Links to High School Activities and Adult Educational Attainment," Developmental Psychology 46 (2010): 258-65; M.J. Irvin, S-Y. Byun, J.L Meece, T.W. Farmer, and B.C. Hutchins, "Educational Barriers of Rural Youth: Relations of Individual and Contextual Difference Variables," Journal of Career Assessment 20 (2012): 71-87.

10. R.A. Petrin, K.A. Schafft, and J.L Meece, "Educational Sorting and Residential Aspirations Among Rural High School Students: What Are the Contributions of Schools and Educations to the Rural Brain Drain?" American Educational Research Journal 51 (2014): 294-326.

11. J. Cromartle, C. von Reichert, and R. Arthun, "Why Some Return Home to Rural America and Why It Matters" (Washington, DC: Economic Research Service, U.S. Department of Agriculture, 2015), https://www.ers.usda.gov/amber-waves/2015/july/whysome-return-home-to-rural-america-and-why-it-matters/.

12. E.H. Sharp, “Out-of-School Time Matters: Activity Involvement and Positive Development Among Coös County Youth," New England Issue Brief \#17 (Durham, NH: Carsey Institute, 2010).

13. J. Seaman, E.H. Sharp, C.J. Tucker, K. Van Gundy, and C. Rebellon, “Outdoor Activity Involvement and Postsecondary Status Among Rural Adolescents: Results From a Longitudinal Analysis,” Journal of Leisure Research 50 (2019): 18-27. 


\section{When We Foster a Sense of Community, Everybody Wins}

1. P.J. Carr and M.J. Kefalas, Hollowing Out the Middle: The Rural Brain Drain and What It Means for America (Boston, MA: Beacon Press, 2009).

2. C.J. Rebellon, N.F. Stracuzzi, and M. Burbank, "Youth Opinions Matter: Retaining Human Capital in Coös County”, New England Issue Brief \#19 (Durham, NH: Carsey Institute, 2010).

3. K.T. Van Gundy, C.J. Rebellon, E.M Jaffee, N.F. Stracuzzi, E.H. Sharp, and C.J. Tucker, "Perceived Local Job Prospects and School Connectedness in a Struggling Rural Economy: A Life-Course Perspective," Peabody Journal of Education 91, no. 2 (2016): 224-45.

4. C.R. Colocousis and J.R. Young, "Continuity and Change in Coös County: Results From the 2010 North Country CERA Survey," New England Issue Brief \#26 (Durham, NH: Carsey Institute, 2011).

\section{Appendix: About the Coös Youth Study}

1. The focus of this section is on the six surveys conducted over ten years, which served as the primary source of data for this report. Interviews were also conducted with a subsample of study participants at three points in time.

2. New Hampshire Department of Education, “NH School and District Profiles," https://my.doe.nh.gov/profiles/.

3. All study communications and appreciation gifts were approved by the University of New Hampshire Institutional Review Board to ensure ethical research conduct.

4. Response rates were calculated using a denominator of total older cohort members who participated during the recruitment period (Waves I and II). Recruitment was discontinued following graduation.

5. Class of 2013 public school enrollment decreased statewide during this period (academic year 2007-2008 to 2012-2013) as well, but by less than 9 percent compared to 23 percent in Coös County.

6. Response rates were calculated using a denominator of total younger cohort members who participated during the recruitment period (Waves I through IV, while they were in school). Recruitment of new participants was discontinued following graduation. 


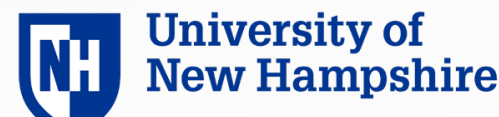

Carsey School of Public Policy

\section{About the Carsey School of Public Policy}

The Carsey School of Public Policy at the University of New Hampshire is nationally recognized for its research, policy education, and civic engagement. The school takes on pressing public issues with unbiased, accessible, and rigorous research; builds the policy and political problem-solving skills of its students; and brings people together for thoughtful dialogue and practical problem-solving.

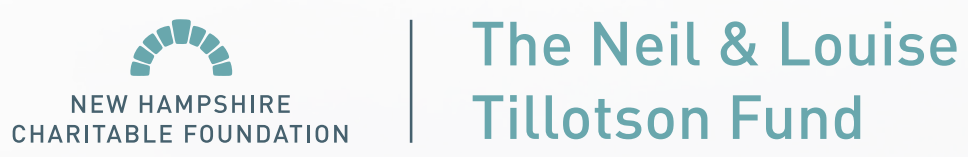

\section{About the New Hampshire Charitable Foundation}

The New Hampshire Charitable Foundation is New Hampshire's statewide community foundation, founded in 1962 by and for the people of New Hampshire. We manage a growing collection of nearly 2,000 funds created by generous individuals, families and businesses, and award more than $\$ 40$ million in grants and scholarships every year. We work with generous and visionary citizens to maximize the power of their giving, support great work happening in our communities, and lead and collaborate on high-impact initiatives.

\section{About the Neil and Louise Tillotson Fund}

The Neil and Louise Tillotson Fund was established at the New Hampshire Charitable Foundation in 2006. The Tillotson Fund is one of the largest permanent rural philanthropies in the country, distributing more than $\$ 3.5$ million annually to support a wide range of community and economic development efforts to help revitalize New Hampshire's Coös County and surrounding communities in Vermont and Québec. The Fund has awarded more than $\$ 40$ million since 2006, and is positioned to continue to support the region in perpetuity.

\section{Acknowledgments}

The authors thank Kirsten Scobie, Yulya Spantchak, Kristen Oliveri, and all the members of the Neil and Louise Tillotson Fund Advisory Committee at the New Hampshire Charitable Foundation; Michael Ettlinger, Curt Grimm, Michele Dillon, Marybeth Mattingly, Laurel Lloyd, and Amy Sterndale from the Carsey School of Public Policy; Charlie Cotton and David Backler, who generously donated their time to serve as external reviewers; and Patrick Watson for editorial assistance. We also acknowledge the hard work of the many talented graduate and undergraduate research assistants who served on this project over its ten years, with special thanks to Meghan L. Mills and Michael S. Staunton. 


\section{N1 University of New Hampshire \\ Carsey School of Public Policy}

Carsey School of Public Policy

University of New Hampshire

Huddleston Hall

73 Main Street

Durham, New Hampshire

03824-3563

603-862-2821

TTY: 7-1-1 (RELAY NH)

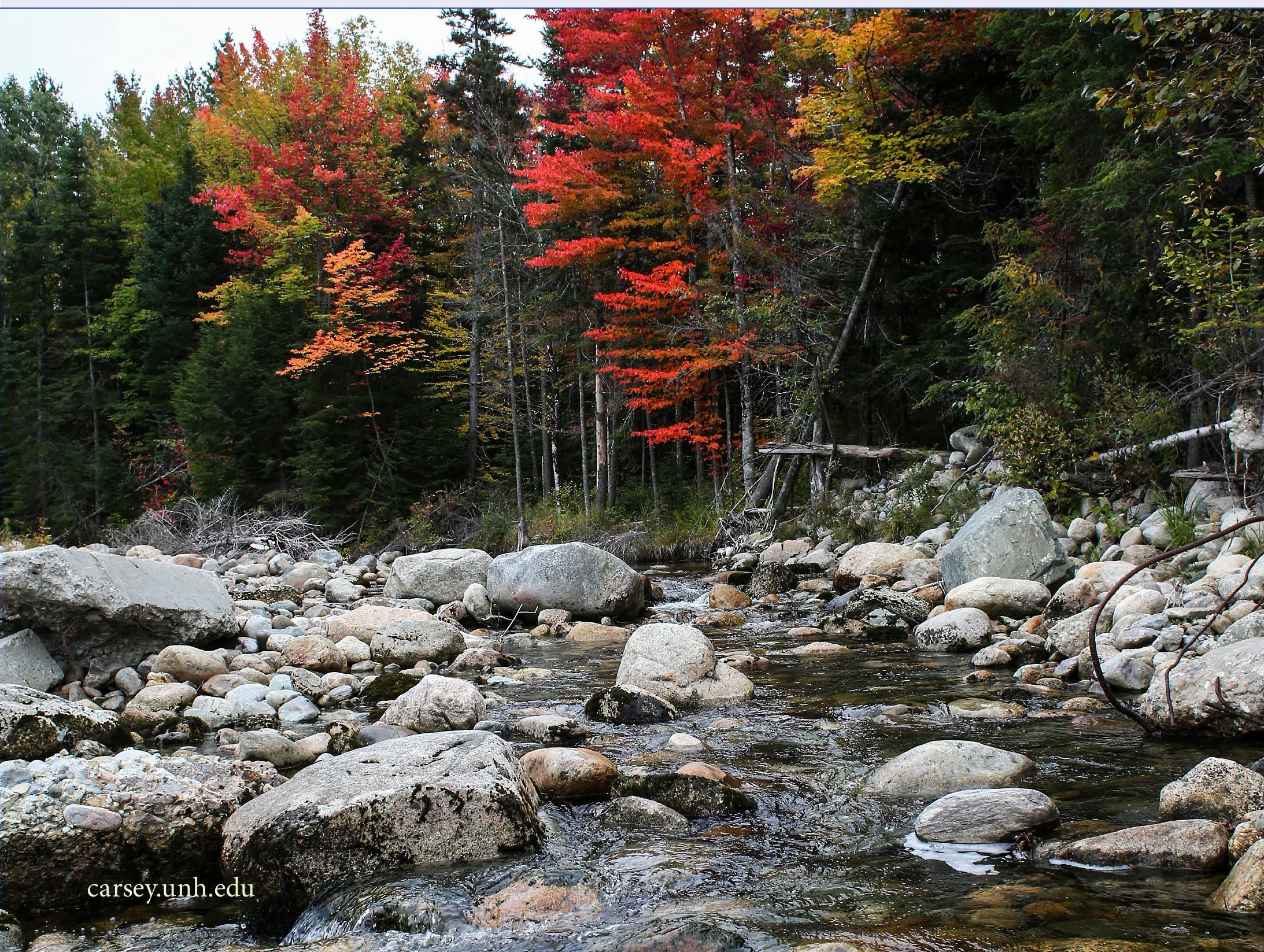

